\title{
Agricultural resources in the Bronze Age city of Tel Lachish
}

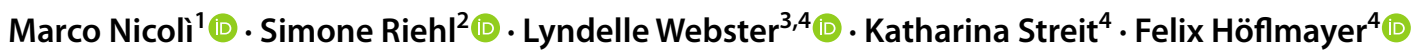

Received: 10 February 2021 / Accepted: 7 January 2022 / Published online: 2 March 2022

(c) The Author(s) 2022

\begin{abstract}
In this paper, we present the results of the plant macrofossil analyses from the site of Tel Lachish, Israel with focus on the botanical assemblage of the Middle and Late Bronze Age layers collected in two different areas of the tell: Area S, a trench on the western edge of the site, whose samples belong to Late Bronze Age deposits, and Area P, the palace area on the top of the mound with samples ranging from the Middle to Late Bronze Age. Systematic sampling of these areas and analysis of the remains have extended our knowledge of the agricultural resources of one of the most influential Late Bronze Age cities in the southern Levant. Multivariate statistics have been applied to gain insight into regional patterns of crop growing. Fruit crops account for the majority of the identified remains from this site, which also included large quantities of Hordeum vulgare (barley) and Triticum dicoccum (emmer wheat) grains. The virtual lack of chaff remains is not solely a matter of preservation, since the Late Bronze Age assemblage preserved fragile small seeds. Rather, this finding suggests that cereal processing took place some distance from the area of deposition. Overall high diversity, ubiquity and proportions of fruit crops indicate that these played a fundamental role in their cultivation and probably also in cultural life at Lachish throughout the 15 th-12th centuries BCE.
\end{abstract}

Keywords Southern levant $\cdot$ Shephelah $\cdot$ Cereal crops $\cdot$ Fruit tree cultivation $\cdot$ Ancient agriculture

\section{Introduction}

Lachish was an urban centre from the Middle Bronze Age (MBA) until the Iron Age (IA), 2000-586 BCE. The tell is among the largest in the southern Levant and is located in the Shephelah region in Israel, between the Mediterranean coast and the Judaean mountains (Fig. 1). Lachish has been the destination of many archaeological expeditions

Communicated by A. Fairbairn.

Marco Nicolì

marco.nicoli@uni-tuebingen.de

1 SFB 1070 "ResourceCultures", Institute for Archaeological Science, University of Tübingen, Rümelinstraße 23 , 72070 Tübingen, Germany

2 Senckenberg Center for Human Evolution and Palaeoenvironment and Institute for Archaeological Science, University of Tübingen, Rümelinstraße 23, 72070 Tübingen, Germany

3 Department of Ancient History, Macquarie University, Sydney, NSW 2109, Australia

4 Austrian Archaeological Institute, Austrian Academy of Sciences, 1020 Hollandstraße 11-13Vienna, Austria throughout the years, starting from the 1930s with the Wellcome-Marston expedition (Torczyner et al. 1938; Tufnell et al. 1940, 1953, 1958) and continuing in the second half of the 20th century, with an expedition directed by Yohanan Aharoni between 1966 and 1968 (Aharoni 1975). A third expedition is the 'renewed excavations', the most extensive excavations, which took place between 1973 and 1994, on behalf of Tel Aviv University and directed by David Ussishkin (Ussishkin 2004). A fourth expedition took place between 2013 and 2016, under the co-direction of Garfinkel, Hasel and Klingbeil (Weissbein et al. 2016; Ganor and Kreimermann 2018; Garfinkel et al. 2021). Since 2017, an Austrian expedition has been excavating two areas which were previously opened by Tel Aviv University, Area S, a deep section on the western edge of the tell, and Area P, the palace area on the top of the mound (Fig. 2). The botanical remains discussed in this paper came from these two areas of specific architectural units (Table 1).

The earliest archaeological finds from Lachish date to the Neolithic period. The pottery evidence points to an occupation of the mound during the Early Bronze Age (EBA), but during the Intermediate Bronze Age (EBA IV) the settlement was almost completely abandoned and excavations 


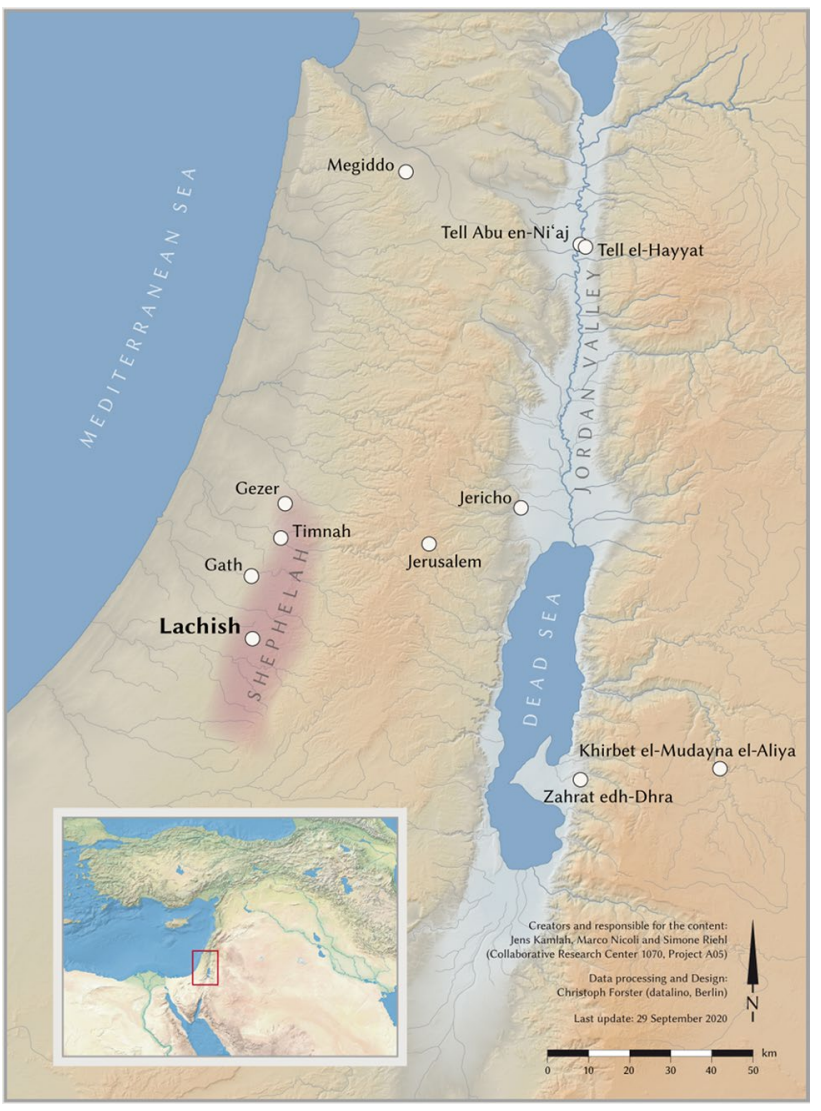

Fig. 1 Map of the southern Levant showing the position of Lachish and some of the other sites mentioned

proved the existence only of small campsites and burials of nomadic tribes on the slope beneath the site (Ussishkin 2004). A renewed settlement and urbanization then occurred during the Middle Bronze Age (MBA), when Canaanite city states began to develop, shown by massive fortifications and a substantial mudbrick building that has been interpreted as a palace. Eventually this MBA city came to a violent end. In the Late Bronze Age (LBA), the city was rebuilt again and it entered the Egyptian sphere of influence. Thanks to the textual evidence of the Papyrus Hermitage 1116A and the Amarna Letters, we know that Lachish was highly valued by the Egyptian rulers, who acknowledged it as one of the most important kingdoms in the southern Levant during this time, together with Gezer and Gath (Tell es-Safi) which are also in the Shephelah (Golénischeff 1913; Epstein 1963; Rainey 2015). Radiocarbon dating of samples from buildings in layer S-3 and contexts within layer S-2 at Lachish, confirm that the site is contemporary with the textual evidence (Webster et al. 2019a, b).

The project "Tracing Transformation" aims to shed new light on the period between the collapse of MBA urbanism and the consolidation of LBA city states. As part of the CRC 1070 Resource Cultures, these archaeobotanical analyses seek to understand the social and cultural changes from the MBA to the LBA from the agricultural resources. Since agriculture and subsistence are fundamental to the social and political functioning of settlements and states, their investigation is crucial for understanding the historical development and external perception of Lachish and other settlements of the region during these periods.

Systematic archaeobotanical sampling has resulted in a large and representative dataset, which helps understand the different aspects of agriculture, such as fruit cultivation, which may have contributed to the importance of Lachish during the LBA. Moreover, by analysing the results through time, this research aims to detect any changes that may have been influenced by climatic fluctuations.

Previous archaeobotanical research in Lachish was mainly on charcoal remains (Liphschitz 2004), whereas seed remains have only been recorded for their overall proportions and ubiquities (Helbæk 1958), which does not allow for comparative studies through time or in various regions. Furthermore, the tendency in earlier analyses to only collect larger seeds leads to their over-representation in the assemblages at the expense of small seeded and wild taxa. The new results presented here fill these gaps and contribute to a better understanding of the agronomic basis of one of the most influential LBA cities in the southern Levant.

\section{Environmental background}

The present-day southern Levant is characterized by a semiarid Mediterranean climate, with a mean annual precipitation of ca. $350 \mathrm{~mm}$ in the Lachish region (Drori and Horowitz 1989). There are no natural springs around the tell, but a seasonal stream runs in the vicinity carrying the name of the city, wadi Lachish. The vegetation of the region is characterized by a Mediterranean carob-lentisk maquis (Zohary 1962) and is heavily affected by human activities like agriculture, viticulture and the introduction of exotic taxa such as Eucalyptus, Cupressus etc. (Olsvig-Whittaker et al. 2015). While faunal data on more or less dry climate elements of datasets from the wider region show only a little difference between the LBA and IA environments around Tel Lachish, there is a consistent association with relatively dry environments (Olsvig-Whittaker et al. 2015). Geoarchaeological and pollen studies, however, provide a more varied picture of environmental development there.

The Middle Bronze Age, when a new settlement was established at Lachish leading to the formation of a city state, was a time of semi-arid climate that was moister than today, as shown by the stable oxygen data of the Soreq cave mineral deposits (speleothems), located only about $26 \mathrm{~km}$ northeast of Lachish (Bar-Matthews and Ayalon 2004). This climatic period occurred after a short regional dry event, indicated by the decrease of Mediterranean tree pollen 


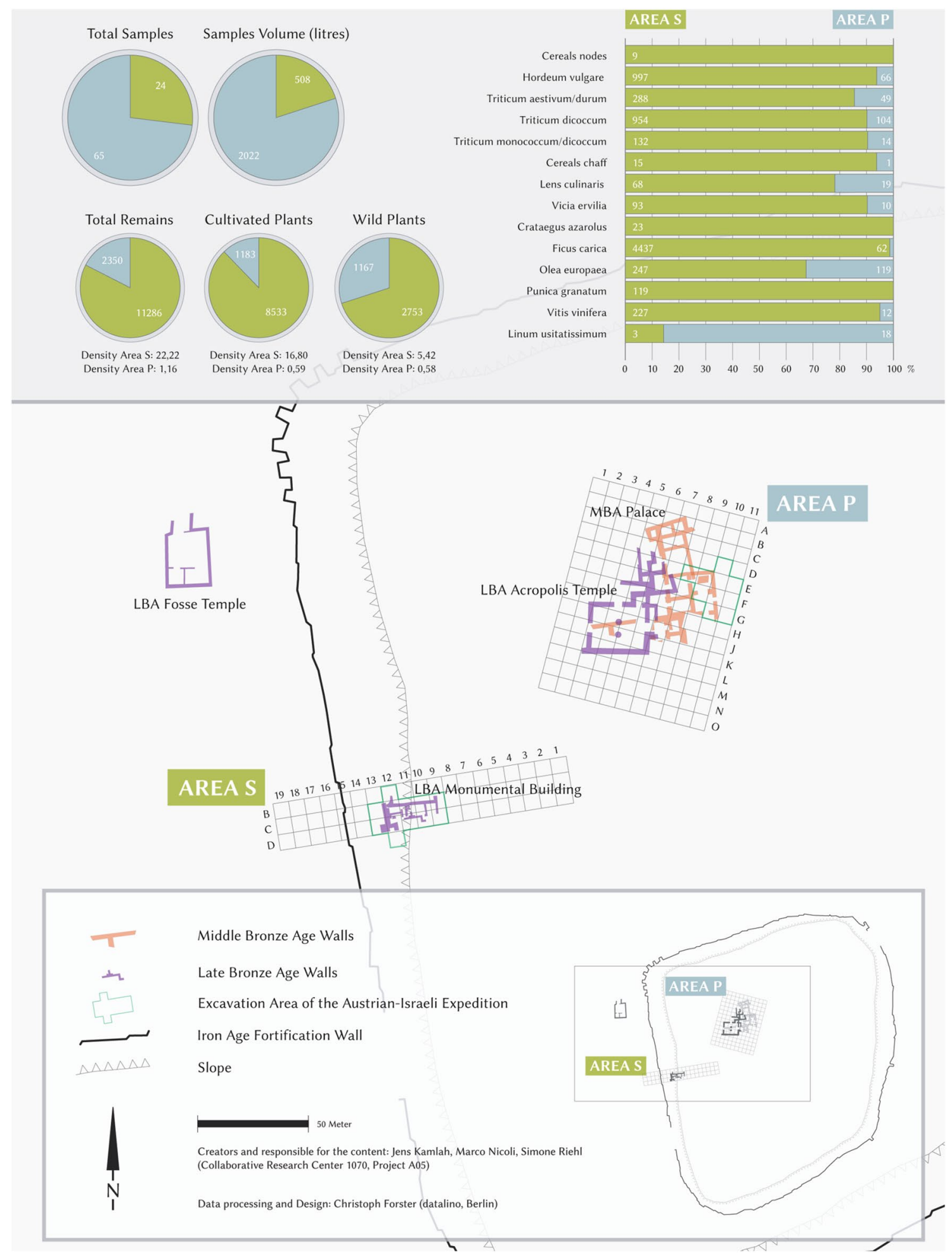

Fig. 2 Lachish, plans of areas S and P. On the top left the sample details (including Iron Age). On the top right the quantities of the main crop remains, the white numbers in the bar chart represent seed counts

values (Langgut et al. 2013). Furthermore, there are signs of rapid fluctuations in rainfall in the Lachish stream sediments at the beginning of MBA I (Rosen 1986). For the LBA, trees and shrubs are recorded in pollen diagrams in which indicate Mediterranean woodlands or maquis scrub with a peak in evergreen Quercus and Pistacia around 1350 все (Langgut 
Table 1 Sampling context and phases in Areas $\mathrm{S}$ and $\mathrm{P}$ (absolute chronology based on Webster 2020)

\begin{tabular}{|c|c|c|}
\hline Layer & Absolute chronology ${ }^{a}$ & Description \\
\hline \multicolumn{3}{|l|}{ Area $S$} \\
\hline$S-3 c$ & $1495-1440$ все, $1 \sigma$ & Late Bronze Age I: fortification, monumental building and domestic units \\
\hline$S-3 b$ & $1460-1430$ все, $1 \sigma$ & Re-use of monumental building and new domestic units \\
\hline S-3a & $1445-1420$ все, $1 \sigma$ & Re-use of monumental building and new domestic units \\
\hline S-2 & 1435-1305 вСЕ, $1 \sigma$ & Late Bronze Age II waste context \\
\hline \multicolumn{3}{|l|}{ Area $P$} \\
\hline $\mathrm{P}-4$ & $1618-1573$ все, $1 \sigma$ & Middle Bronze Age III, last use of the palace \\
\hline $\mathrm{P}-3$ & $1605-1530$ все, $1 \sigma)$ & Re-use of the palace building for industrial/domestic purposes \\
\hline P-2 & са $1200-1300$ ВСЕ & Late Bronze Age II structures and pits \\
\hline
\end{tabular}

${ }^{a}$ Numerical ranges include both the start and end boundaries of each phase; see Webster et al. (2019a,b; 2020) et al. 2015), coinciding with a time of prosperity in the city state. The rich arboreal vegetation is also shown in LBA pollen samples from Lachish, showing a peak in Mediterranean maquis trees (in particular Pinus halepensis) but also higher values of Olea europaea compared with the MBA and IA pollen spectra (Drori and Horowitz 1989). At the end of the LBA, another dry climate event occurred in the Levant, as shown not only by a reduction in arboreal pollen but also by a strong increase in $\delta^{18} \mathrm{O}$ and $\delta^{13} \mathrm{C}$ values in the speleothems of Soreq cave, Jerusalem (Bar-Matthews and Ayalon 2004). Additional signs of increased aridity comes from the isotopic composition of plankton in Mediterranean sea cores on the coastal plain (Schilman et al. 2002). Studies carried out in the Dead Sea area suggest an earlier start of this dry event at around 1500 BCE (Migowski et al. 2006; Kagan et al. 2015), although dating results from different lines of evidence have not been correlated yet. The Iron Age has been associated with a less dry climate (Langgut et al. 2013, 2015). Both modern ecological data and archaeobotanical assemblages from sites located in the Coastal Plains and the Shephelah (Shfela) suggest a shift from mesic to xeric biomes for the LBA/IA transition, except for Lachish which falls into the xeric class throughout the whole sequence investigated (Olsvig-Whittaker et al. 2015). Nevertheless, in Lachish, a rich arboreal pollen record collected from floors, artificial fillings, contents of pottery and mudbricks, has been found from IA layers similar to those of the LBA, showing a Mediterranean environment which is comparable to the present day one, but less arid (Drori and Horowitz 1989).

Since the environmental results appear elusive in terms of fluctuations in aridity and partially contradictory, a consideration of the general environmental pattern as obtained from charcoal studies at Lachish and other sites in the Shephelah may be more conclusive. These data have not shown any major changes in the tree and shrub composition, the three main taxa during the EBA, LBA and IA being Olea europaea, Quercus calliprinos and Pistacia palaestina (Liphschitz 2004).

\section{Material and methods}

During the 2018 and 2019 excavation seasons, 89 archaeobotanical samples were collected. Each sample was between 5 and $70 \mathrm{~L}$, based on the archaeological context, but the majority measured $30 \mathrm{~L}$, amounting to a total volume of about $2,530 \mathrm{~L}$ of sediment which was collected at the tell. These samples were processed using a flotation machine with a water recycling system built at the site in 2018 (ESM Fig. 1). There are 24 samples from Area $S$ and 65 from Area P (Fig. 2), belonging to four different periods or phases (ESM Table 1). The samples from Iron Age IIA (4 samples) and IIB (1 sample), which belong solely to Area P (phase $\mathrm{V}$ and IV), are not included in the overall evaluation due to their small sample size.

The heavy residues from the flotation were collected on a $1 \mathrm{~mm}$ mesh inside a large barrel, dried and then sorted into three groups for plant remains, fauna and small archaeological finds (beads, etc.). The light fraction, the flot, was collected on a $0.2 \mathrm{~mm}$ sieve, then dried on small pieces of linen cloth.

The plant remains collected from both the heavy and the light fractions were sent to the archaeobotanical laboratory at the University of Tübingen for study. Plant remains were identified using an Euromex stereo microscope with up to $30 \times$ magnification using the Senckenberg seed reference collection available there (with roughly 20,000 seed taxa), various identification keys, recently published archaeobotanical research, seed catalogues and floras (for example, Post 1980; Jacomet 2006; Kislev et al. 2006; 2009a; b; Nesbitt 2009; Neef et al. 2012; Danin and Fragman 2016; Rousou et al. 2021). In a few cases, where the light fraction $(0.2 \mathrm{~mm})$ was larger than $200 \mathrm{ml}$, a riffle type sample splitter was used to produce sub-samples of one half or less (for Area S: L.1187, L.1122; Area P: L.2049). Most of the seed remains were charred, but some mineralized seeds were also present among some taxa, such as some specimens of Vitis vinifera, Ficus carica and Cyperaceae. 
For some seeds, species identification was impossible due to bad preservation and, in some cases, breakage or the lack of surface texture limited identification to genus level. For example, in the case of Triticum monococcum/ dicoccum, the grains, sometimes badly preserved, showed characteristics of both species. In side view, the biconvex outline morphologically categorizes them as one-grained einkorn. The apexes were however characteristic of slender emmer grains, making it impossible to identify them as either emmer or einkorn.

Some wild plant taxa have not been identified to the species level. Most of these seeds lack important identification features such as the mericarp in Malva sp. or surface patterns in small seeded pulses. Most of the Poaceae remains were not preserved in complete form, making it possible only to identify them to genus level, as in the case of Bromus spp., Avena sp. and Phalaris spp.

The samples from Area $\mathrm{P}$ were heavily affected by modern contamination, mainly within the light fractions which were packed with roots. A considerable number of remains from Area P were heavily corroded and cereal grains showed the typical expanded "bubble" pattern, except for the remains from pit L. 2049.

Weighing was used to quantify highly fragmented seeds and fruitstones (especially olives), and then converted into equivalent complete seeds from the weight of a complete individual. In cases where only one fragment was present, it was considered as one seed. Additionally, two halves and four quarters of cereal grains have been counted as one. Percentages and ubiquity of the recorded taxa and correspondence analysis (CA) for comparison between sites was done with CANOCO v. 5. Plant remains were photographed using a Zeiss Stereo Discovery V8 digital microscope (Figs. 3, 4).

\section{Results}

The botanical assemblage is composed of 58 identified taxa, which includes 20 cultivated plants from a total of 9,714 remains and 38 wild plant taxa from 3,920 remains. The plant remains from the various phases of the LBA ( $\mathrm{S}-3, \mathrm{~S}-2$ and P-2), MBA III (P-4 and P-3) and Iron Age II are given in Tables 2 and 3. IA samples will not be discussed in this paper due to their rarity, nevertheless, the plant remains identified from these samples have been listed in the tables to comply with open data access requirements.

\section{Cereals}

A total of 4,203 cereal remains were identified (Table 2). The best represented is Hordeum vulgare (barley, Fig. 3a), with a total of 1,063 grains and 13 rachis remains (Fig. 3b) representing $21 \%$ of all MBA crop remains and $11 \%$ of
LBA crop remains. In terms of quantity, Triticum dicoccum (emmer wheat, Fig. 3c), is very close to barley in numbers, with a total of 1,058 grains and two glume bases (Fig. 3d), making up $10 \%$ of the MBA remains and $11 \%$ of the LBA crop assemblage. After barley and emmer, Triticum aestivum/durum (free-threshing wheat) follows with 337 grains (2\% of MBA and $3.5 \%$ of LBA crop assemblages) and a single rachis fragment. Although barley is dominant in Area $\mathrm{S}$, emmer is the main wheat in Area P. Particularly in Area P, cereal fragments were badly preserved and therefore identified only as Cerealia.

\section{Fruit}

The majority of the identified crop remains are of fruit. Ficus carica (fig) (Fig. 3i) is the crop with the highest number of seeds from LBA Lachish, with $47 \%$ of the total, but only $17 \%$ of the total MBA crop remains. Olea europaea (olive) (Fig. 3k) is the only fruit present in all analysed periods, and it is the most frequently represented taxon from the site, with 20 olive stones for MBA III (13\% of the cultivated remains) and 343 for the LBA (3.6\%). Vitis vinifera (grape) (Fig. 3q) is the next in terms of seed quantity from fruit, with a total of 239 remains representing $2.5 \%$ of both the MBA and LBA crop remains.

Punica granatum (pomegranate) is represented by 83 seeds and 36 exocarp fragments in a well-preserved state (Fig. 3n, o) and they are only present in LBA contexts since the remains come from Area S (25\% of the LBA samples). The other two taxa from this category include one fruitstone of Phoenix dactylifera (date) (Fig. $31 \mathrm{~m}$ ), and 23 Crataegus azarolus remains (azarole or Mediterranean medlar) (Fig. 3g, h), all of which come from LBA contexts in Area S.

\section{Other crops}

Vicia ervilia (bitter vetch) is the most abundant pulse in LBA contexts (1\% of LBA crop remains). Lens culinaris (lentil) is the main legume found in the MBA samples, representing 3\% of the MBA crop assemblage. Other legumes are Cicer arietinum (chickpea), Lathyrus sativus (grass pea), Pisum sativum (pea) and Vicia faba var. minor (faba bean) (Fig. 3e, f), which are present in small numbers. Linum usitatissimum (flax) is concentrated in a few LBA contexts, comprising 20 seeds and one capsule (Fig. 3s).

\section{Wild plants}

Overall, 38 wild plant taxa were identified from Lachish (Table 3). Lolium cf. temulentum (Fig. 4d) is the commonest wild plant from the LBA contexts, with a total of 3,206 remains and it is present in more than half of the samples. In 
Fig. 3 Hordeum vulgare (barley) (L.1122), a grain, b rachises (L.1122); Triticum dicoccum (emmer wheat) (L.1212), c grain, $\mathbf{d}$ glume base; Vicia faba var. minor (faba bean) (L.1212), e lateral view, $\mathbf{f}$ front view; Crataegus azarolus (azarole) (L.1132), $\mathbf{g}$ top view, $\mathbf{h}$ bottom view; Ficus carica (fig), i seeds (L.1122), j mineralized seeds (L. 2038); k Olea europaea (olive) (L.1122); Phoenix dactylifera (date) (L.1132), 1 lateral view, $\mathbf{m}$ top view; Punica granatum (pomegranate) (L.1187), $\mathbf{n}$ seeds, o exocarp fragment; Vitis vinifera (grape), p mineralized pip (L.2049), q pip (L.1187); Linum usitatissimum (flax), $\mathbf{r}$ seed (L.2049), $\mathbf{s}$ seed and capsule (L.1212), t capsule detail (L.1212); scale bars $=1 \mathrm{~mm}$ except for a, $\mathrm{g}$, $\mathrm{h}=2 \mathrm{~mm}$ and $\mathrm{k}, 1, \mathrm{~m}=5 \mathrm{~mm}$

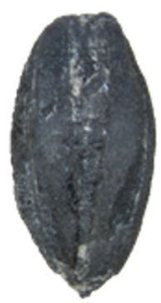

a

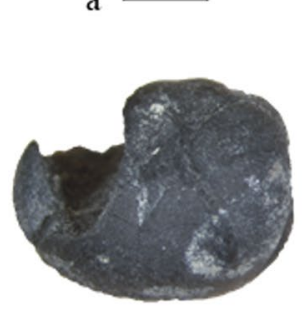

e -

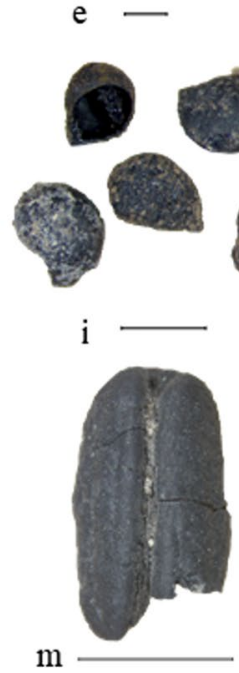

$\mathrm{m}$

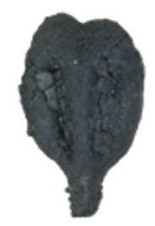

$\mathrm{q}-$

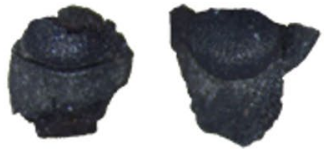

b

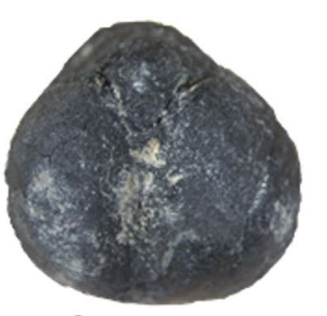

f

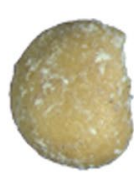

c
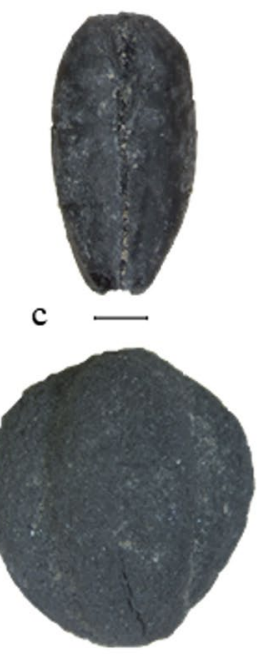

$\mathrm{g}$

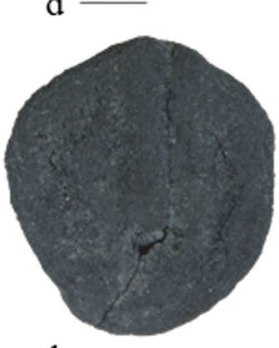

$\mathrm{h}$

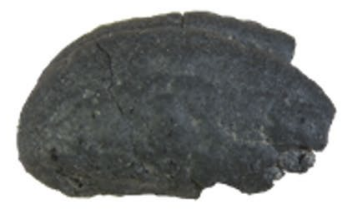

$\mathrm{k}$
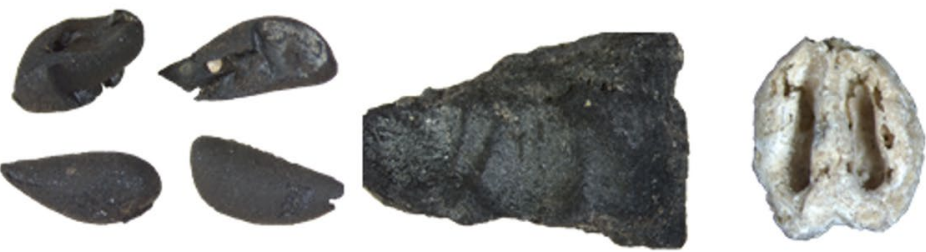

$0-$

$\mathrm{p} \longrightarrow$
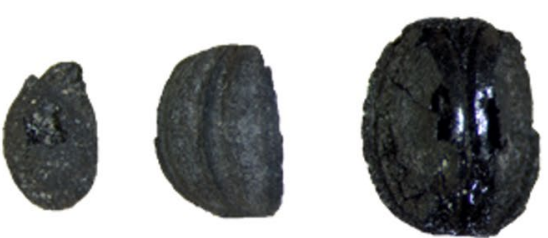

s

$\mathrm{t}$ terms of ubiquity, Chenopodium sp. (Fig. 4c) is found from all periods. Few remains of Pistacia (lentisc) were identified and one of the seeds showed damage caused by an insect (Fig. 4i).

Other wild plants have been found, such as Plantago lanceolata, Phalaris sp., Bromus sp. and including Malva sp. (Fig. 4e), which is the most frequent wild plant in the MBA III samples.

Several small wild leguminous taxa like Medicago sp. (48 seeds) and Scorpiurus cf. muricatus (55 seeds) were found solely in LBA samples from Area S contexts (S-3 and S-2). Furthermore, and only from this period, are 19 Cephalaria cf. syriaca (Fig. 4b) seeds and 16 Cyperaceae seeds.

\section{Charcoal}

Wood charcoal remains constitute a large proportion of the archaeobotanical remains found in Lachish, with a total of 6,706 large and small fragments recovered. Of these, 5,116 came from the MBA contexts in Area P.

The analyses of these by Katleen Deckers are in progress, but the first results for the MBA contexts show a large amount of Pinaceae, mainly Cedrus sp. (cedar), Pinus sp. and Olea europaea. These results partially confirm the previous charcoal analysis carried out for the site by Nili Liphschitz during the excavations directed by David Ussishkin, which and were mainly on wood samples from MBA, LBA 
Fig. 4 a Capparis spinosa (caper) (modern and L.2049), seeds; b Cephalaria $\mathrm{cf}$. syriaca (L.2049); c Chenopodium (L.1197); d Lolium cf. temulentum (darnel) (L.1122); e Malva (mallow) (L.2136); Plantago lanceolata (ribwort plantain) (L.2049), f seed, $\mathbf{g}$ seed including a modern specimen; h Polygonaceae (L.2049); i Pistacia terebinthus (terebinth) (L.1212); j Thymelaea passerine (L.1122); Torilis leptophylla (L. 2049), $\mathbf{k}$ front view; $\mathbf{l}$ back view; $\mathbf{m}, \mathbf{n}$ Tribulus terrestris (L.1187); scale bars $=1 \mathrm{~mm}$
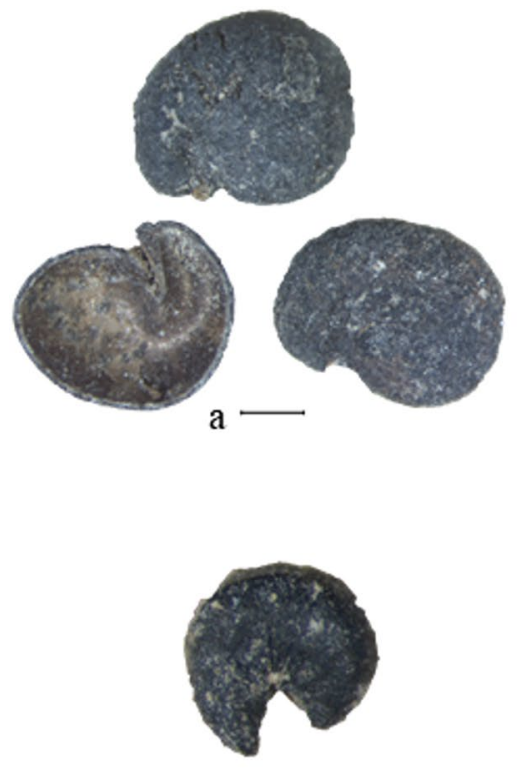

$\mathrm{b}$
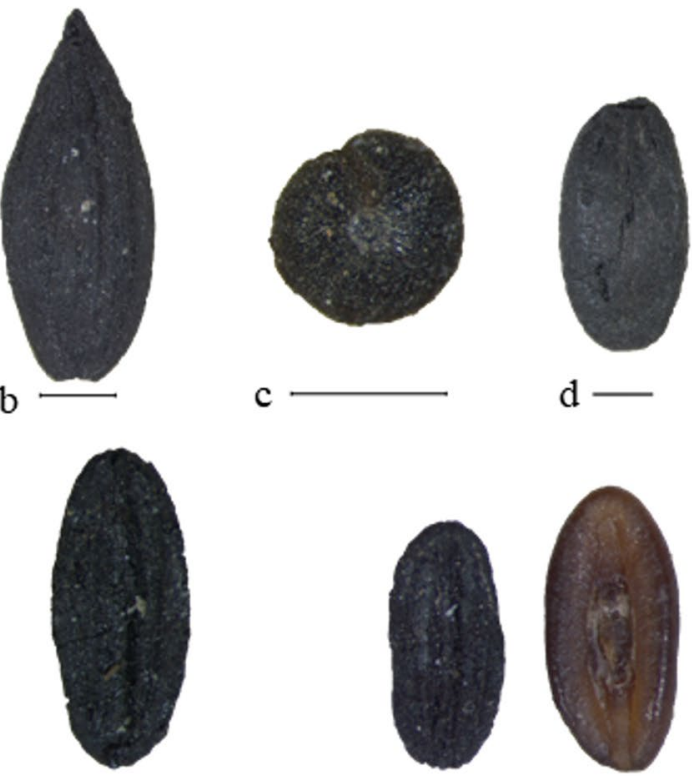

$$
\text { e }
$$

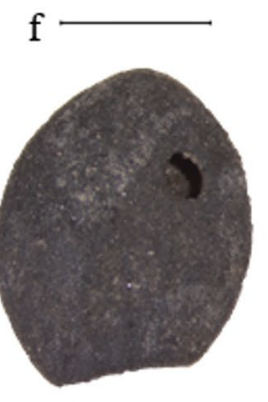

i

$\mathrm{m}$ -
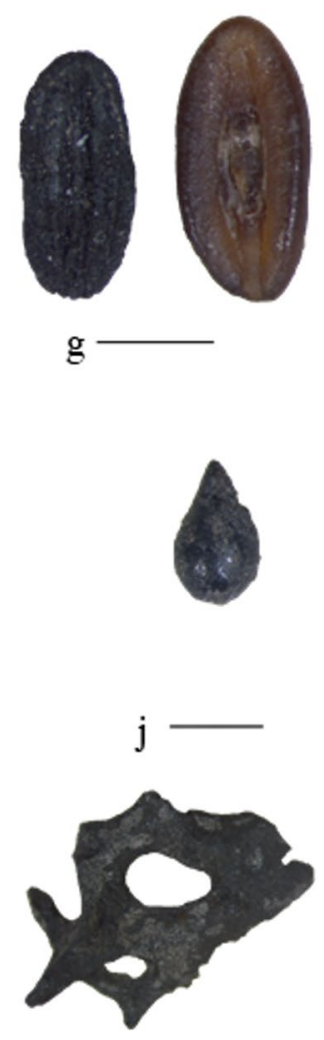

$\mathrm{g}$

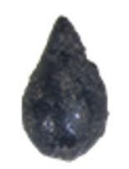

$\mathrm{n}-$ and IA layers (Liphschitz 2004). Most of the wood remains were of O. europaea, followed by Quercus calliprinos, Pistacia sp. and Cedrus libani (cedar of Lebanon). In the MBA contexts, O. europaea and Cedrus libani were the two most frequent taxa. Olea was also the most represented fruitstone identified by Liphschitz.

\section{Contextual considerations of the plant assemblages}

\section{Composition of the plant assemblages through time periods}

In comparing plant assemblages through time, it is important to note that much of the new archaeobotanical data is well dated, and many samples are directly radiocarbon dated. In addition to Table 1 , summarized plots of ${ }^{14} \mathrm{C}$ dates for the main MBA and LBA levels from which remains were archaeobotanically analysed, are provided in Fig. 5. The full data can be consulted in Webster et al. (2019a, b) and Webster (2020).

Tables 2 and 3 list the cultivated and wild plants for the three periods, MBA III, LBA and IA II. Only five IA II samples were collected from Area $\mathrm{P}$, producing a very small number of remains and taxa, mainly Hordeum vulgare and O. europaea for cultivated plants and Chenopodium for wild plants.

The number of samples and their total volume are similar for the MBA III and LBA, but considerably more remains 
Table 2 Cultivated plants identified from Lachish, by period

\begin{tabular}{|c|c|c|c|c|c|c|c|c|c|}
\hline Area & $\mathrm{P}$ & & & $\mathrm{S}$ and $\mathrm{I}$ & & & $\mathrm{P}$ & & \\
\hline Period & Mido & $\mathrm{e} \mathrm{Br}$ & ze III & Late B & onze & & Iror & Age II & \\
\hline Samples $(n)$ & 36 & & & 48 & & & 5 & & \\
\hline Volume (L) & $\sim 1,1$ & & & $\sim 1,19$ & & & $\sim 1$ & & \\
\hline & $n$ & $\%$ & Ubiq. (\%) & $n$ & $\%$ & Ubiq. (\%) & $n$ & $\%$ & Ubiq. (\%) \\
\hline Cereals & & & & & & & & & \\
\hline Cerealia (frag.) & 31 & 20 & 36 & 1,091 & 11 & 83 & 1 & 10 & 20 \\
\hline Cereal culm nodes & & & & 9 & 0.1 & 8.3 & & & \\
\hline Hordeum vulgare & 32 & 21 & 44 & 1,025 & 11 & 77 & 6 & 60 & 40 \\
\hline Triticum aestivum/durum & 3 & 2 & 8.3 & 334 & 3.5 & 45 & & & \\
\hline T. dicoccum & 16 & 10 & 27 & 1,042 & 11 & 62.5 & & & \\
\hline T. monococcum/dicoccum & 2 & 1 & 5.5 & 144 & 1.5 & 43.7 & & & \\
\hline$T$. sp. (frag.) & 8 & 5 & 13.8 & 443 & 5 & 45.8 & & & \\
\hline Cereal chaff ${ }^{\mathrm{a}}$ & 1 & 0.6 & 2.7 & 15 & 0.15 & 16 & & & \\
\hline Legumes & & & & & & & & & \\
\hline Cicer arietinum & & & & 3 & 0.03 & 4.2 & & & \\
\hline Fabaceae (frag.) & 4 & 2.5 & 8.3 & 12 & 0.13 & 16 & & & \\
\hline Lathyrus sativus & 1 & 0.6 & 2.7 & 27 & 0.3 & 25 & & & \\
\hline Lens culinaris & 5 & 3 & 11 & 82 & 0.9 & 41.6 & & & \\
\hline Pisum sativum & & & & 5 & 0.05 & 8.3 & & & \\
\hline Vicia ervilia & 2 & 1 & 5.5 & 101 & 1 & 43.7 & & & \\
\hline V. faba var. minor & & & & 3 & 0.03 & 6.2 & & & \\
\hline Fruit & & & & & & & & & \\
\hline Crataegus azarolus & & & & 23 & 0.2 & 14.5 & & & \\
\hline Ficus carica & 26 & 17 & 33 & 4,471 & 47 & 66 & & & \\
\hline Olea europaea & 20 & 13 & 55 & 343 & 3.6 & 83 & 3 & 30 & 40 \\
\hline Phoenix dactylifera & & & & 1 & 0.01 & 2 & & & \\
\hline Punica granatum ${ }^{\mathrm{b}}$ & & & & 119 & 1.25 & 25 & & & \\
\hline Vitis vinifera & 4 & 2.5 & 8.3 & 235 & 2.5 & 48 & & & \\
\hline Others & & & & & & & & & \\
\hline Linum usitatissimum & & & & 21 & 0.22 & 8.3 & & & \\
\hline Total & 155 & 100 & & 9,549 & 100 & & 10 & 100 & \\
\hline
\end{tabular}

ancludes: 13 Hordeum, 1 Triticum aestivum/durum rachises, 2 Triticum dicoccum glume bases

${ }^{b}$ Includes: 36 exocarp fragments were recovered from the LBA samples. MBA III samples are dominated by $H$. vulgare, followed by Ficus carica, $O$. europaea and Triticum dicoccum, while in the wild plant assemblage Malva sp. and Polygonaceae were mainly found. It is worthwhile noting that $76.3 \%$ of the charcoal remains come from this period. From the LBA samples there is a substantial increase of remains compared with the MBA and new taxa appear, mostly $F$. carica followed by $T$. dicoccum and $H$. vulgare, T. aestivum/durum and then $O$. europaea and Vitis vinifera. Olive remains show a remarkably high ubiquity which is in agreement with earlier investigations of EBA and IA samples (Helbæk 1958).

Some taxa were exclusively found in LBA samples, such as Punica granatum and Crataegus azarolus. Many different wild plant taxa appear in this period and its assemblage is largely dominated by Lolium cf. temulentum, which also occurred in higher proportions in the IA samples studied by Helbæk (1958).

\section{Interpretation of the sampling locations by their contexts and functions}

The results of the identifications from the two areas show how the proportion of plant remains differs between Areas $\mathrm{S}$ and $P$ (Fig. 2). The density of remains from Area $S$ is much higher, even though from Area $\mathrm{P}$ more samples and a greater volume of sediment were collected. 
Table 3 Wild plants identified from Lachish, by period

\begin{tabular}{|c|c|c|c|c|c|c|c|c|c|}
\hline \multirow{3}{*}{$\begin{array}{l}\text { Area } \\
\text { Period } \\
\text { Samples (n) }\end{array}$} & \multicolumn{3}{|l|}{$\mathrm{P}$} & \multicolumn{3}{|c|}{$\mathrm{S}$ and $\mathrm{P}$} & \multicolumn{3}{|l|}{$\mathrm{P}$} \\
\hline & \multicolumn{3}{|c|}{ Middle Bronze III } & \multicolumn{3}{|c|}{ Late Bronze } & \multicolumn{3}{|c|}{ Iron Age II } \\
\hline & 36 & & & 48 & & & 5 & & \\
\hline \multirow[t]{2}{*}{ Volume (L) } & \multicolumn{3}{|c|}{$\sim 1,150$} & \multicolumn{3}{|c|}{$\sim 1,197$} & \multicolumn{3}{|c|}{$\sim 183$} \\
\hline & $\mathrm{n}$ & $\%$ & Ubiq. (\%) & $\mathrm{n}$ & $\%$ & Ubiq. (\%) & $\mathrm{n}$ & $\%$ & Ubiq. (\%) \\
\hline Ajuga sp. & 1 & 1.5 & 2.7 & & & & & & \\
\hline Apiaceae & & & & 5 & 0.13 & 6.2 & & & \\
\hline Asperula sp. & 2 & 2.9 & 5.5 & 2 & 0.05 & 4.2 & & & \\
\hline Asphodelus sp. & & & & 1 & 0.03 & 2 & & & \\
\hline Avena sp. & & & & 3 & 0.08 & 4.2 & & & \\
\hline Brassicaceae & & & & 1 & 0.03 & 2 & & & \\
\hline Bromus sp. & 6 & 8.7 & 8.3 & 13 & 0.34 & 12.5 & & & \\
\hline Capparis spinosa & & & & 2 & 0.05 & 4.2 & & & \\
\hline Carthamus sp. & & & & 1 & 0.03 & 2 & & & \\
\hline Cephalaria cf. syriaca & & & & 19 & 0.5 & 8.3 & & & \\
\hline Chenopodium album & 1 & 1.5 & 2.7 & 34 & 0.9 & 8.3 & 16 & 26.2 & 60 \\
\hline Ch. cf. murale & 6 & 8.7 & 11.1 & 35 & 0.92 & 14.5 & 40 & 65.6 & 100 \\
\hline Ch. sp. & & & & 1 & 0.03 & 2 & & & \\
\hline Coronilla sp. & & & & 1 & 0.03 & 2 & & & \\
\hline Cyperaceae & & & & 16 & 0.42 & 8.3 & & & \\
\hline Euphorbia sp. & 1 & 1.5 & 2.7 & 1 & 0.03 & 2 & 5 & 8.2 & 40 \\
\hline Galium cf. aparine & & & & 6 & 0.16 & 10.4 & & & \\
\hline Muscari sp. & 1 & 1.5 & 2.7 & 16 & 0.42 & 4.2 & & & \\
\hline Lithospermum arvense & & & & 1 & 0.03 & 2 & & & \\
\hline Lolium cf. temulentum & 6 & 8.7 & 8.3 & 3,206 & 84.56 & 58.3 & & & \\
\hline Malva sp. & 12 & 17.4 & 19.4 & 93 & 2.45 & 33 & & & \\
\hline Medicago sp. & & & & 48 & 1.27 & 30 & & & \\
\hline Melilotus sp. & & & & 3 & 0.08 & 6.2 & & & \\
\hline Phalaris sp. & 3 & 4.3 & 8.3 & 64 & 1.69 & 23 & & & \\
\hline Phleum sp. & & & & 8 & 0.21 & 4.1 & & & \\
\hline Pistacia lentiscus & & & & 11 & 0.29 & 10.4 & & & \\
\hline P. terebinthus & & & & 2 & 0.05 & 2 & & & \\
\hline$P$. sp. & 3 & 4.3 & 8.3 & 21 & 0.55 & 12.5 & & & \\
\hline Plantago lanceolata & 7 & 10.1 & 11.1 & 64 & 1.69 & 27 & & & \\
\hline Poaceae & & & & 7 & 0.18 & 8.3 & & & \\
\hline Polygonaceae & 13 & 18.8 & 8.3 & 1 & 0.03 & 2 & & & \\
\hline Scorpiurus cf. muricatus & & & & 55 & 1.45 & 20 & & & \\
\hline Silene sp. & 1 & 1.5 & 2.7 & 1 & 0.03 & 2 & & & \\
\hline Torilis leptophylla & & & & 5 & 0.13 & 4.2 & & & \\
\hline Tribulus terrestris & & & & 1 & 0.03 & 2 & & & \\
\hline Trifolium sp. & 3 & 4.3 & 5.5 & 25 & 0.66 & 23 & & & \\
\hline Trigonella sp. & & & & 8 & 0.21 & 10.4 & & & \\
\hline Thymelaea passerina & 1 & 1.5 & 2.7 & 4 & 0.1 & 4.2 & & & \\
\hline Undetermined & 2 & 2.9 & & 6 & 0.16 & & & & \\
\hline Total & 69 & 100 & & 3,791 & 100 & & 61 & 100 & \\
\hline
\end{tabular}

\section{Area S}

24 samples totalling about $508 \mathrm{~L}$ sediment were collected from Area S (Fig. 6) and from this deep section, 8,533 cultivated and 2,753 wild plant remains were identified. Area $\mathrm{S}$ has the highest plant remains density of 22.22 remains/L (Fig. 2). 
Fig. 5 Radiocarbon chronology for Area S (top) and Area P (bottom) using Bayesian analysis. The summarized plots show estimated transitions between layers that are of interest to the archaeobotanical study. The dates were calibrated with OxCal (Bronk Ramsey 2009) and the latest calibration curve, IntCal20 (Reimer et al. 2020)
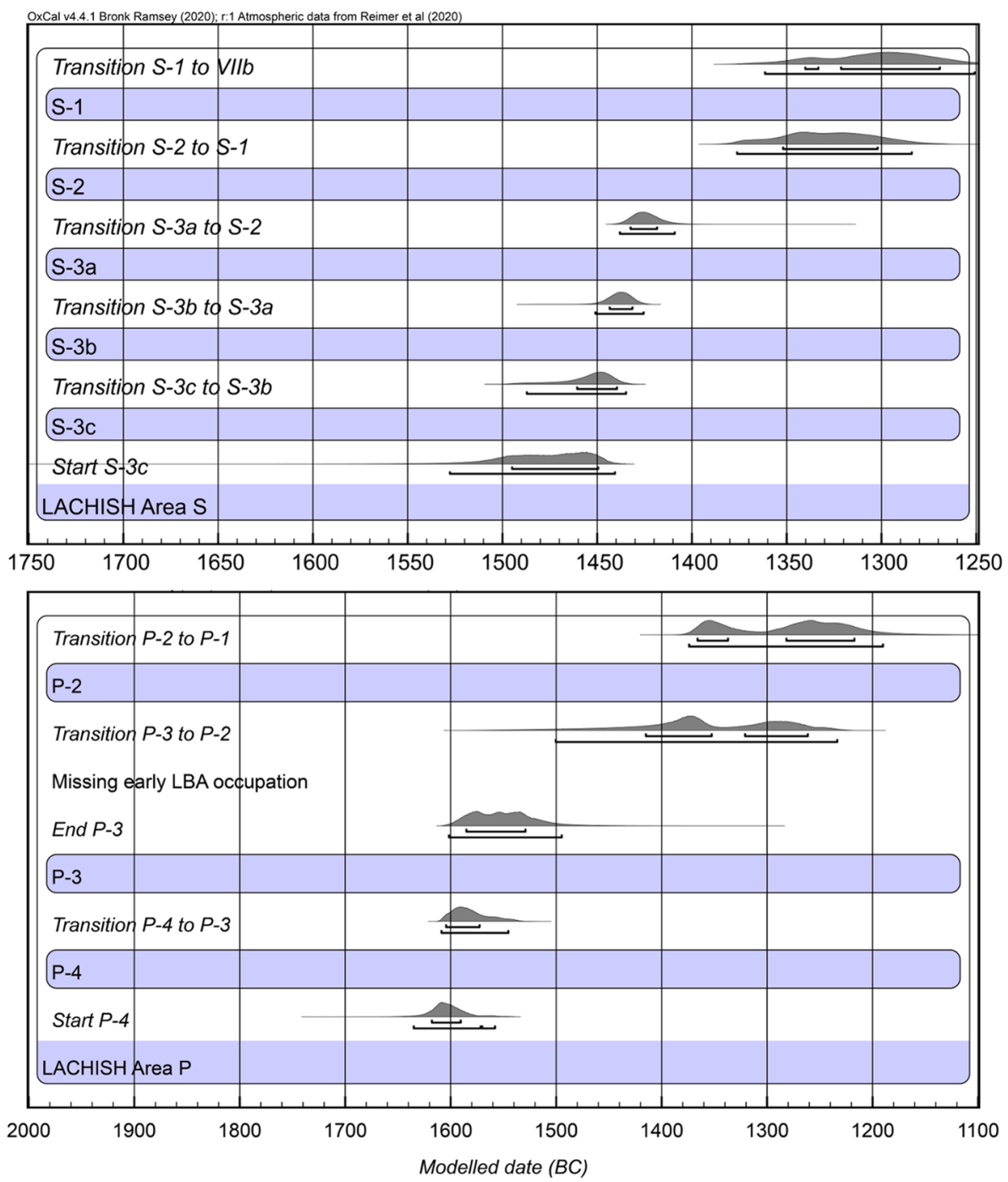

The samples derive almost exclusively from LBA layers S-3c-a and S-2. Layer S-3c features a monumental building and a fortification wall, and dates to 1495-1440 вСE. S-3b and S-3a, 1460-1420 вСЕ, represent a period when the fortification wall went out of use, but the monumental building was reused, with additional smaller structures built to the south. In S-3 a series of deposits began to accumulate in Area $\mathrm{S}$ with numerous burnt layers interspersed with fill and surfaces, some plastered. This deposition continued in layer S-2 (1435-1305 BCE), after the monumental building went out of use, with the deposits now extending across almost the whole excavation area.

Square D11 provided most of the plant remains from the 2018 season, from four samples from layer S-3a collected in square D11, specifically from L.1122, a layer which included a plastered floor and associated burnt remains, L.1121, a burnt layer directly overlying L.1122, and L.1132, another burnt layer running immediately below L.1122. Note that the dating of S-3a derives from these and other closely associated contexts. From these three contexts, a large amount of $T$. dicoccum and $H$. vulgare were found together with most of the small number of chaff remains identified from the site, ten Hordeum rachises and one of T. aestivum/ durum. However, the largest number of remains from this square are of $F$. carica with 996 seeds (including three mineralised ones), accounting for the $22 \%$ of the total number found in Area S. Furthermore, these three contexts have yielded large quantities of various other fruit taxa, $85 \% O$. europaea (209 olive stones), making D11 the square from which the highest quantity of olives were found, and $59 \%$ of the $V$. vinifera (134 pips) found in Area S.

The highest number of Lolium cf. temulentum seeds, nearly $55 \%$ of its total remains from Lachish, were found from this square.

Square C12 represented deep fill layers that were deposited directly next to the fortification wall and monumental building and included frequent patches of black burnt remains, rich in charcoal. A single context, L.1187 (S-3b-c), 


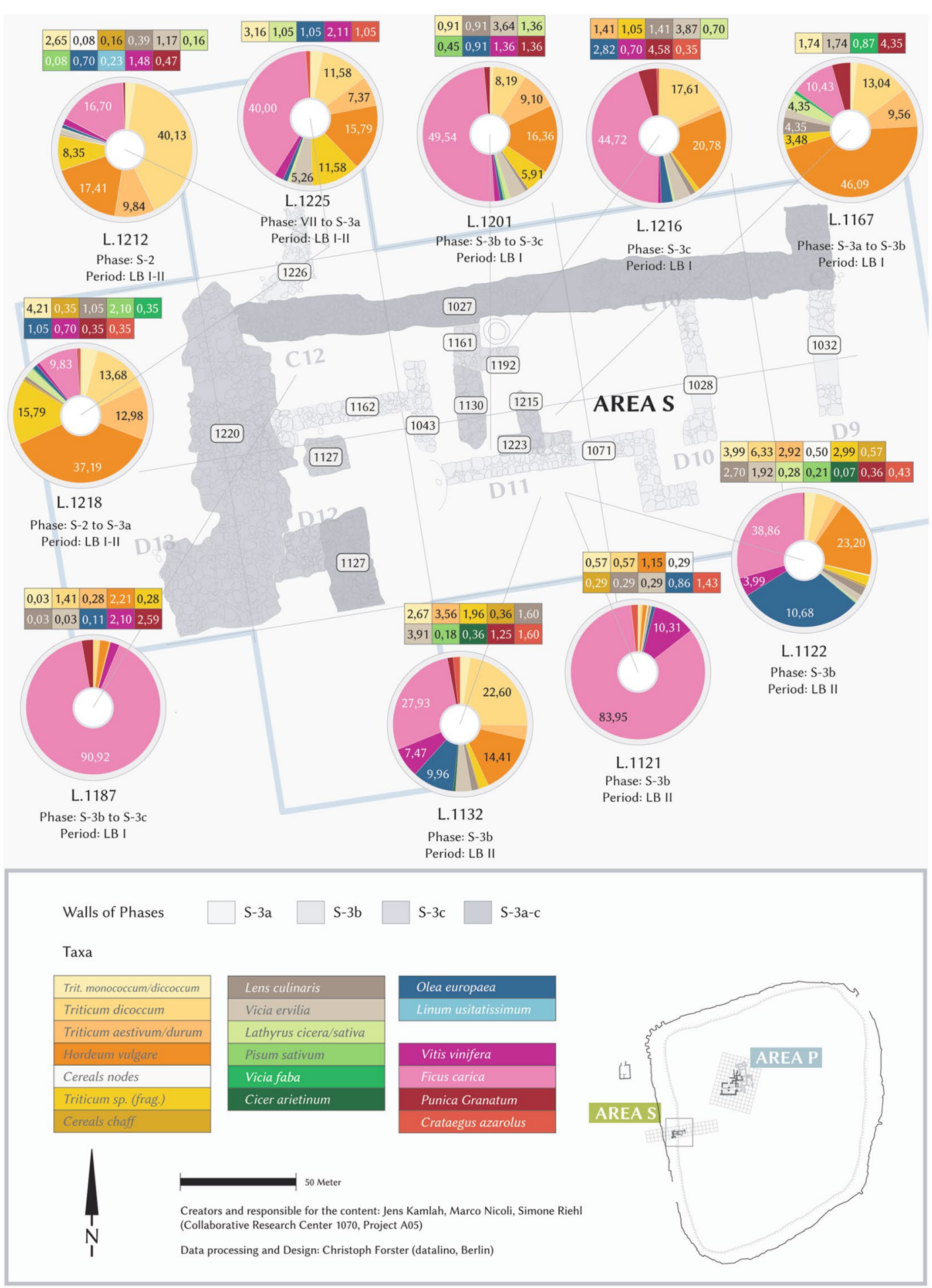

Fig. 6 Lachish, Area S. Pie charts representing the percentages of crop remains from selected samples

was sampled from this square and many seeds were identified from it. Ficus amounts to $58.6 \%$ of the total fig pips from the whole site; square $\mathrm{C} 12$ also provided $68 \%$ of the Punica remains, together with a large number of Vitis (61 seeds), H. vulgare (64 grains) and T. dicoccum (41 grains).
Most of the remains from this square were found in a different state of preservation compared with the other contexts of Area S, showing what appears to be a compressed state.

In another square, C11, a tabun clay oven was discovered in 2018 from which two samples (S-3b) were collected, 
which provided only a few botanical remains, though sufficient to provide ${ }^{14} \mathrm{C}$ dates for this material. In 2019, a floor was excavated in layer S-3c and samples were collected from the burnt layers above it, also used for dating. From these samples (L.1216) the same pattern of cereals from the previous squares was identified, with barley and emmer being the main taxa in terms of quantity and fig still the most frequent one.

Square B12 was excavated in 2019 to start a new investigation inside the monumental building in Area S. From this, ten samples were collected from S2, resulting in large numbers of barley (365 grains), emmer (606 grains), Fig. (506 seeds, $12 \%$ mineralized) and Lolium cf. temulentum (462 seeds). Moreover, the only Linum usitatissimum (flax) remains from Area $\mathrm{S}$ were found here, two seeds and part of a seed capsule. It may be noted that the ca. $20-30 \mathrm{~cm}$ thick ash layer from which the archaeobotanical samples were taken can be traced with images from the Tel Aviv University expedition southwards across the area, where it ran over the disused wall of the monumental building and equates to the S-2 deposit to the south, in square D11, though here it is represented by a laminated deposit with multiple burnt layers.

\section{Area $P$, palace area}

A total of 65 samples were collected from the palace area, with a sediment volume of about 2,022 L. These samples provided 1,183 remains of cultivated plants and 1,167 of wild plants. This area was heavily affected by modern contamination and the preservation of the remains was mediocre (Fig. 4a). This is shown by the large amount of Cerealia and Triticum sp. grain fragments in the archaeobotanical assemblage, in fact, in many cases, complete identification could not be achieved. The samples derive primarily from MB III layers P-4 and P-3, ${ }^{14} \mathrm{C}$ dated to ca $1650-1550$ BCE and from LBA layers P-2/1, broadly dated to 1300-1200 BCE. Layer P-4 represents the last use of the MBA palace, which ended in its fiery destruction. Shortly afterwards, the building was rebuilt and used for industrial and domestic purposes before being destroyed for a second time. LB I is poorly represented in Area $\mathrm{P}$, but subsequently a domestic building (P-2/1) replaced the palace.

\section{L.2049}

A 1.6 m deep Late Bronze Age pit, L2049, was found in Area P (P-2), square F10, during the 2018 excavation. Interpreted as an offering pit, this included a large deposit of black charred material together with complete vessels in situ, a jug, a Mycenaean straight-sided alabastron (a pottery or glass container for oil or perfume) and a bowl (Fig. 7). Note that the two currently available dates for layer P-2 are from pit L.2049. Eight samples were collected from different levels in this pit, with a total volume of nearly 270 L. A total of 1,946 plant remains were recovered, $82.8 \%$ of the total remains from Area $\mathrm{P}$, marking the importance of this pit for the whole assemblage (Tables 2,3 ). The quantity of finds decreased near the bottom of the pit where the soil was denser and more organic. The samples taken from the bottom of the pit and slightly above provided all the taxa found in L.2049.

The cultivated plants from this pit were mainly cereals, with a large amount of Cerealia and Triticum sp. grain fragments. Triticum dicoccum (86 grains), T. aestivum/durum (46 grains) and Olea (80 stones) were the most numerous remains, but it is worth also noting the large numbers of seeds from wild plants, Cephalaria cf. syriaca (17), Chenopodium album (25), Phalaris sp. (50), Plantago lanceolata (55) and a large quantity of Lolium cf. temulentum (821).

The main assemblage of Linum usitatissimum came from this LBA pit, with $85.7 \%$ of all the flax, emphasizing again its presence in this period.

Areas S and P are structurally, contextually and taphonomically different areas, as reflected in the results from them. Area P, located on the top of the mound, was always an elite area where palaces were located in various periods. While the nearly total absence of chaff remains in Area $\mathrm{P}$ can be explained by poor preservation due to disturbance of the soil as suggested by the heavy modern contamination, this interpretation is not applicable to Area S, a deep excavated trench with much better preserved botanical remains located on the edge of the tell. Here the relative absence of chaff must be explained differently, since other fragile seeds, such as flax and fig are preserved there. Most likely, cereal processing took place at some distance from the area of deposition. Based on the archaeological finds, the contexts of squares D11 and C12 can probably be associated with the dumping of waste material, even though $\mathrm{C} 12$ has yielded many and various well preserved remains, revealing an extraordinary depositional history. For example, L.1187 (S-3), the lowest layer of a fill outside the monumental building, dominated Area $\mathrm{S}$ and was enclosed by small walls. It was rich in pottery, animal bones and charred plant remains. The plant remains consisted mainly of fig, followed by grape and pomegranate (including exocarp fragments), barley, emmer and few wild plant remains. Some of these remains had been highly compressed before charring, but still preserved enough of their diagnostic features to allow a complete identification. Some other seeds were 
in a semi-mineralized state. These preservation conditions were probably because L.1187 was the lowest layer in a waste context outside the monumental building, based on the archaeological finds and the spatial setting. It will be important to enlarge the excavation in Area $S$ to be able to better understand the context and the function of this structure.

\section{Lachish internal phases}

Due to the small number of remains in the individual samples from the Area P layers P-4 (11 samples and 55 remains) and P-3 (20 samples, 45 remains), a detailed comparison between these phases is not possible. However, they both contain the same taxa, matching the pattern for the MBA III samples described previously.

In Area S, samples from buildings and fortification contexts in phase S-3 yielded a larger quantity of remains of crops compared to the waste contexts (middens) in phase S-2 (Table 4). Fruit remains dominate S-3, with Ficus found in each S-3 sample, representing $64.35 \%$ of the assemblage but Vitis (3.7\%), Olea (3.78\%) and Punica (1.8\%) are also present in large quantities compared to S-2. Cereals were less abundant from the fortification context and the most frequent one, Hordeum, represents $10.35 \%$ of the assemblage. The remains from phase S-2 are mainly figs and cereals, but while the main cereal from the S-3 samples is Hordeum, from S-2 it is Triticum dicoccum (27.86\%). Some pulses and fruit taxa, Cicer arietinum (chickpea), Pisum sativum (pea), Crataegus azarolus (a hawthorn) and Phoenix dactylifera (date), are absent from the S-2 phase of waste deposition. The only taxon present from S-2 but not from S-3 is Linum usitatissimum.

\section{The Late Bronze Age plant assemblage from Tel Lachish in its regional context}

The Late Bronze Age crop data from several settlement sites in the southern Levant have been compared using correspondance analysis (CA) (Fig. 8). Sites with only presence/ absence data were excluded as well as those with less than five crop taxa, since small samples may be unrepresentative of farming and subsistence practices. Similarly, taxa that occur from less than four sites have not been included to avoid any "noise" in the graph that could conceal real patterns (Jones 1991).

It was not possible to remove the omnipresent species such as O. europaea, H. vulgare and F. carica due to the limitation of the data, after the initial exclusions, which would not have reached a minimum threshold needed to plot the graphs, considering that only crop taxa are considered. The results from Beth-Shean (Simchoni et al. 2007), Tell es-Safi (Gath) (Mahler-Slasky and Kislev 2012) and Timnah (Kislev et al. 2006) stand out from other sites by their dominance in free-threshing wheat. Tell es-Safi (Gath) and Timnah are located close to each other in the Shephelah (Fig. 1). The inhabitants of Beth-Shean, which is further away, did not grow wheat locally due to low mean annual precipitation there, and no evidence of irrigation has been found. The presence of exotic weeds at the site suggested trade in crops with distant agricultural lands (Simchoni et al. 2007).

Aphek is isolated from the other groups, located in the positive part of the first axis and negative part of the second axis, and is associated with large numbers of Vitis and Linum. Located on the central coastal plain of Israel, on the Yarkon river, Aphek has a more moderate, less arid, environment which distinguishes it from the other sites (Kislev 2009a; Olsvig-Whittaker et al. 2015).

Another group of sites, comprising Tell Der 'Alla (Van Zeist and Heeres 1973) and Kamid el-Loz (Baas 1980; Behre 1970), are concentrated in the upper part of the diagram, characterized by a large amount of barley. Tell Der 'Alla, located on the east side of the Jordan valley shares the same richness in Hordeum as other LBA sites in this region, such as Tall al- 'Umayri (Ramsay and Mueller 2016) and Tell el-Hayyat (Metzger 1984), as they show a similar trend to sites located in Lebanon, on the coast near Sidon and in the Beqaa valley, such as Kamid el-Loz.

The other sites, including Lachish, cluster in the upper right part of the diagram and are concentrated around a dense area of taxa consisting of $T$. dicoccum, some legumes and most of the fruit, Olea, Punica and Ficus.

Figure 9 shows the occurrence of crop taxa in the sites and their frequency represented by the size of the circles. Barley is the only taxon present in each site, followed by free-threshing wheat and grape.

\section{Discussion}

Lachish has the closest affinities with Pella and Sidon, as shown in the correspondance analysis results. Pella is situated in the foothills of the Jordan valley, $5 \mathrm{~km}$ east of the river Jordan. The site is located on a large artificial mound, separated from a natural hill by a perennial spring and stream (Bourke et al. 2006). This stream would have offered irrigation possibilities while the modern mean annual rainfall of $300 \mathrm{~mm}$, which is close to that of Lachish, is sufficient for dry farming (Wilcox 1992). The plant assemblage for the Bronze Age is not as well represented as the other periods due to a limited number of samples, but it is clear that Pella, with its abundant finds of Hordeum, is similar to the other sites in the northern and eastern Jordan valley. The other cereal found from there is T. dicoccum, but the fruit finds are limited to a single Vitis (Wilcox 1992). The other site with similarities to Lachish is Sidon, which is on the coast of Lebanon and is bordered by two rivers to the north 
Fig. 7 Lachish, Area P. Photos of L.2049 pit with vessels in situ. On the bottom, two graphs showing the percentages of cultivated and wild plant remains from the pit
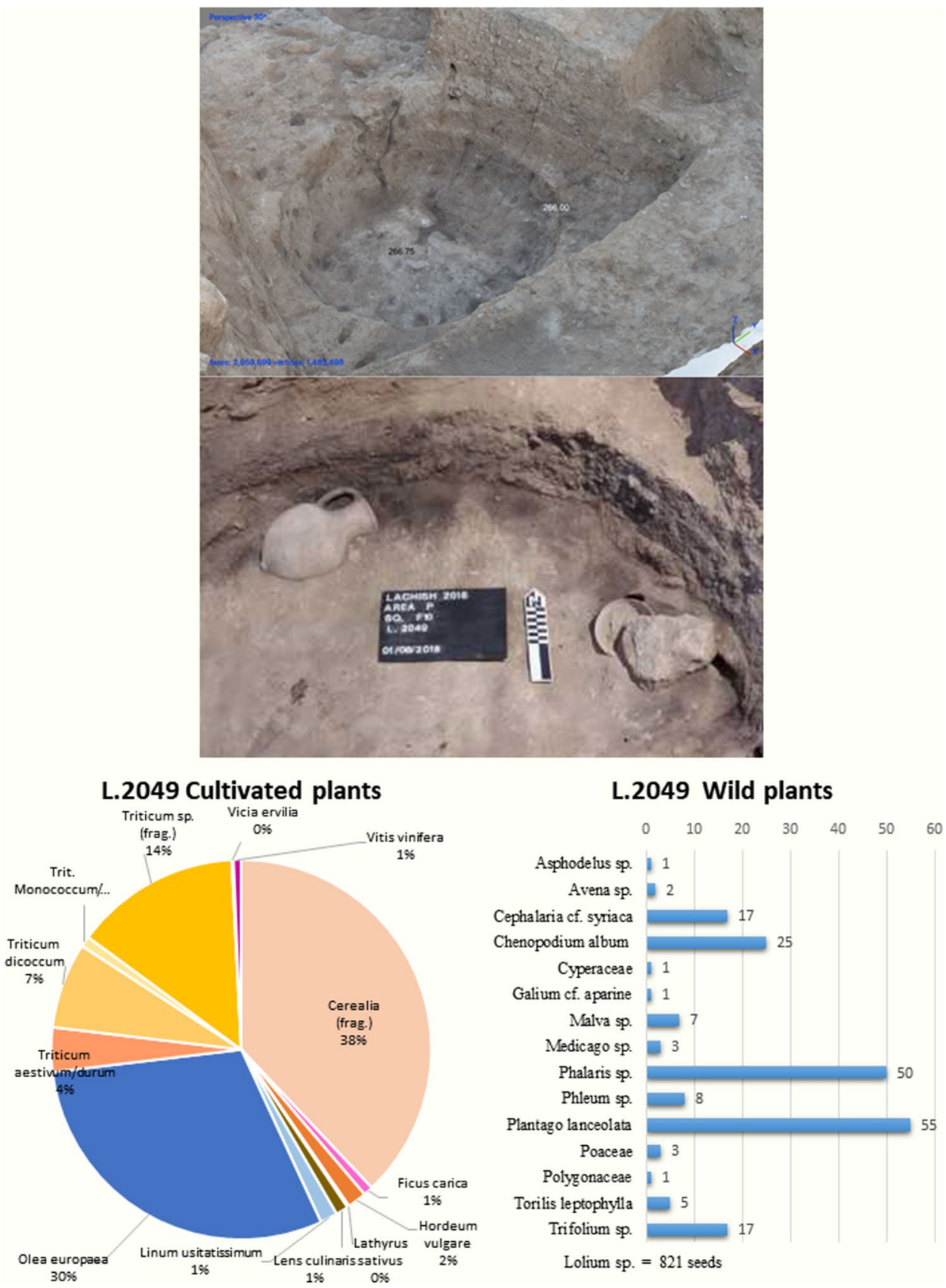

and south of the city, and to the east by the escarpment of Mount Lebanon, and has a mean annual precipitation around 650-700 mm. During the Late Bronze Age, Sidon was one of the most active ports on this coast, making it an important centre for trade (Carayon et al. 2011). The LBA botanical assemblage from Sidon is composed mainly of olive stones, the most frequent crop plant, followed by barley. As with Pella, the only other cereal and fruit found in Sidon are emmer and grape (De Moulins 2015).

Barley is the main crop found from both LBA Pella and Sidon and also from phase S-3 at Lachish. Moreover, olive was the most frequent crop remain found at both Sidon and Lachish.

The LBA sites mostly group around free-threshing wheat, emmer and barley as shown by the correspondance analysis, except for Aphek and some other sites.

The position of Lachish compared to the other LBA sites in the Shephelah is relatively close only to Tel Burna (Orendi 2018), creating a different cluster opposed to Tell es-Safi (Gath) and Timnah, where free-threshing wheat was the dominant cereal (Kislev et al. 2006; Mahler-Slasky and Kislev 2012), while at Lachish, emmer was the most abundant cereal along with a great quantity of barley. 
Barley, which is present in all LBA sites, was also an important part of the human diet at Lachish as indicated by its high ubiquity in Area S.

Like barley, emmer and free-threshing wheat have yielded almost no chaff remains with just one T. aestivum/durum rachis and two T. dicoccum glume bases, as in the case in Tell es-Safi (Gath) and Timnah, which may be interpreted as a sign that threshing was not done within the cities.

It is interesting to notice the main changes in cereals between phases S-3 and S-2 at Lachish (Table 4). S-3 yielded a large quantity and variety of crop remains, including cereals, mainly barley. The samples from the later phase S-2 contained mainly cereal grains, but here $T$. dicoccum (emmer) dominates the assemblage. Assuming that these different layers represent successive time periods, the dominance of emmer seems to agree with the crop production strategy in Egypt at the time (Nesbitt and Samuel 1996).

From the Late Bronze Age, Linum usitatissimum starts appearing in the assemblages from S-2 and P-2. Flax is a water demanding crop and notably $87.5 \%$ of Plantago lanceolata seeds were obtained from the same contexts. P. lanceolata has oval seeds with broad rims and dorsal ridges,

Table 4 Cultivated plants identified from Lachish Area S, by layer

\begin{tabular}{|c|c|c|c|c|}
\hline \multirow{3}{*}{$\begin{array}{l}\text { Area S phases } \\
\text { Samples (Vol., L) }\end{array}$} & \multicolumn{2}{|l|}{ S-3 } & \multicolumn{2}{|l|}{$\mathrm{S}-2$} \\
\hline & \multicolumn{2}{|c|}{$14(330)$} & \multicolumn{2}{|c|}{$6(136)$} \\
\hline & $n$ & $\%$ & $n$ & $\%$ \\
\hline Cerealia (frag.) & 187 & 3.06 & 375 & 18.79 \\
\hline Cereal culm nodes & 8 & 0.13 & 1 & 0.05 \\
\hline Cicer arietinum & 3 & 0.05 & & \\
\hline Crataegus azarolus & 21 & 0.34 & & \\
\hline Fabaceae (frag.) & 9 & 0.15 & 1 & 0.05 \\
\hline Ficus carica & 3,931 & 64.35 & 440 & 22.04 \\
\hline Hordeum vulgare & 632 & 10.35 & 242 & 12.12 \\
\hline Lathyrus sativus & 15 & 0.25 & 2 & 0.1 \\
\hline Lens culinaris & 60 & 0.98 & 5 & 0.25 \\
\hline Linum usitatissimum & & & 3 & 0.15 \\
\hline Olea europaea & 231 & 3.78 & 11 & 0.55 \\
\hline Phoenix dactylifera & 1 & 0.02 & & \\
\hline Pisum sativum & 5 & 0.08 & & \\
\hline Punica granatum & 110 & 1.8 & 8 & 0.4 \\
\hline Triticum aestivum/durum & 104 & 1.7 & 140 & 7.01 \\
\hline T. dicoccum & 348 & 5.70 & 556 & 27.86 \\
\hline T. mопососсит/dicoссит & 79 & 1.29 & 38 & 1.9 \\
\hline T. sp. (frag.) & 81 & 1.33 & 131 & 6.56 \\
\hline Cereal chaff & 11 & 0.18 & 3 & 0.15 \\
\hline Vicia ervilia & 72 & 1.18 & 16 & 0.80 \\
\hline$V$. faba minor & 1 & 0.02 & 1 & 0.05 \\
\hline Vitis vinifera & 200 & 3.27 & 23 & 1.15 \\
\hline Total & 6,109 & 100 & 1,996 & 100 \\
\hline
\end{tabular}

clearly differing from the other Plantago species (Figs. 4f, g). It can be associated with relatively moist habitats (Danin and Fragman 2016), suggesting that flax was cultivated in an area with easy access to additional water sources as opposed to the cornfields. Besides P. lanceolata, many other local weeds have been identified and, as in the case of Lolium cf. temulentum, found in large quantities together with cereal grains. In Area S-3, square D11 provided nearly $68 \%$ of the chaff remains and $89 \%$ of the cereal culm nodes together with most of the $L$. cf. temulentum seeds, and we can presume that this was part of a working or storage area on the tell. Even though some Lolium species could have been used as fodder (Malleson 2015), L. temulentum (darnel) is considered a noxious weed and had an unintentional role in the human diet when mixed with wheat, since it was difficult to separate the weed seeds from the cereal grains (Kislev et al. 2009b).

Lolium cf. temulentum, Phalaris sp. and Cephalaria syri$a c a$ are weeds, commonly associated with crops using winter rain, a common practice in Late Bronze Age Shephelah (Zohary 1950; Frumin et al. 2019), so that irrigation may have not been extensively used. This applies especially for

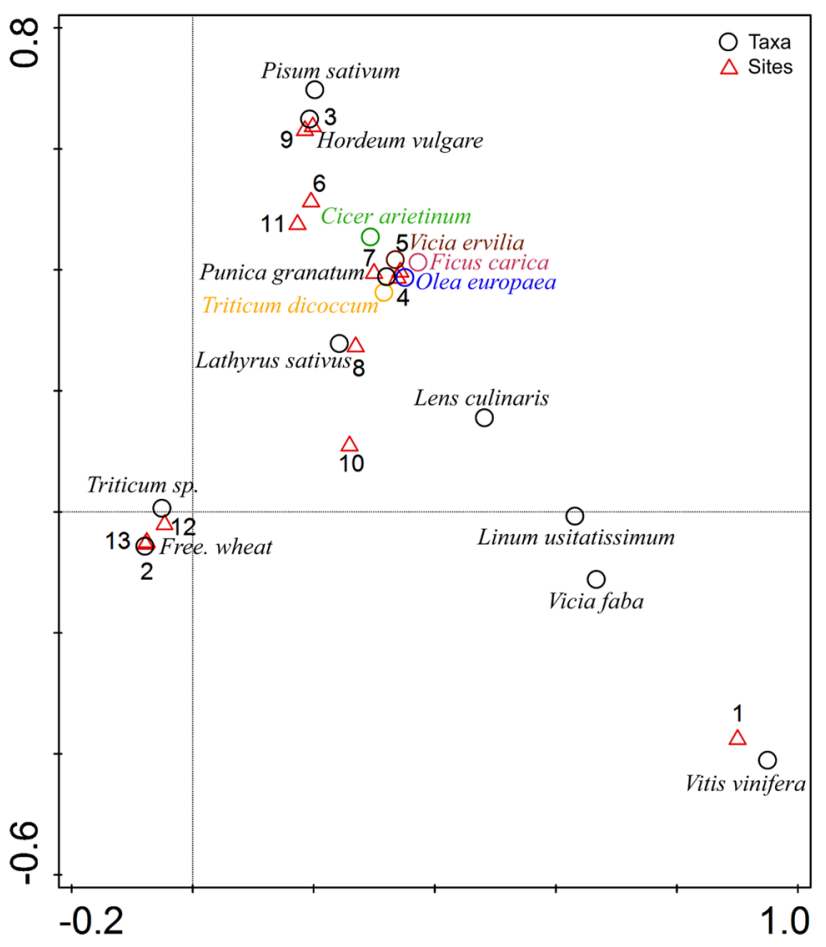

Fig. 8 Correspondence analysis biplot of Southern Levant LBA sites and crop taxa. FreeWheat $=$ free threshing wheat (cumulative variance, Axis $1=27.35$, Axis $2=53.30$; Eigenvalues Axis $1=0.9370$, Axis 2=0.8889). 1, Aphek; 2, Beth-Shean; 3, Kamid el-Loz; 4, Lachish; 5, Pella; 6, Qubur el-Waleyide; 7, Sidon; 8, Tel Burna; 9, Tell Der 'Alla; 10, Tell el-Burak; 11, Tell el- 'Umeri; 12, Tell es-Safi (Gath); 13, Timnah 
Lachish phase S-3 from where more than the $85 \%$ of the $L$. cf. temulentum seeds from Area S have been found.

\section{Fruit growing}

The first archaeobotanical work on Lachish was published in 1958 by Hans Helbæk, and in the Early Bronze Age and Iron Age samples, the presence of cereals and fruit stands out. The main cereals in the EBA samples are emmer wheat and barley, whereas in the IA samples they are mainly freethreshing wheat, which providing a distinct sequence of cereal cultivation over time, from emmer and barley during the EBA to the LBA, then changing to free-threshing wheat in the Iron Age. The small number of samples in these early studies must be noted, five EBA and 7 LBA. The fruit that Helbæk mainly found were olive, but also grape and $\mathrm{Cra}$ taegus azarolus, a hawthorn which grows around the whole Mediterranean basin, but is no longer much eaten. It still has frequent use in traditional Arab medicine in Israel, where it is considered an important resource of antioxidants and a remedy for treating cardiovascular diseases (Ljubuncic et al. 2005) and its foliage is still used as fodder for sheep and goats. C. azarolus is scattered in the present natural scrub of the Shephelah as part of the widespread carob lentisk maquis that dominates the natural landscape of the region (Hepper 1992; Olsvig-Whittaker et al. 2015).

The presence of fruit orchards, vineyards and olive groves around Lachish is based on several lines of evidence. The most ubiquitous taxon on the site is O. europaea, present in $69.7 \%$ of the samples, which shows an emphasis on olive growing around the city. Fig, grape, pomegranate, date and C. azarolus are also present. This pattern of olive, fig and pomegranate remains is shared by all the other LBA sites in the Shephelah, giving another clue to the past local diet (Frumin et al. 2019). It is interesting to notice also that the presence of a Phoenix dactylifera fruitstone represents a rare find for the Shephelah region. The date stone, characterized by its oblong shape with a deeply grooved furrow, was found in Area S L.1132 in association with all the other fruit remains (Fig. 31, m). Although isolated date stones have been found from as early as Late Chalcolithic Tuleilat Ghassul (Zohary and Spiegel-Roy 1975) or Nahal Mishmar (Zaitschek 1961), they remain rare in the archaeobotanical record of the southern Levant and dates were probably never part of everyday diet. The presence of a date stone at Lachish and the relative absence of Phoenix records from other sites in the region raises the question whether the dates might have been cultivated locally. It is usually assumed that dates were traded between regions through trade networks and as recent finds of date phytoliths in EBA Tell Fadous-Kfarabida, Lebanon (Damick 2019) and in MBA to LBA Megiddo, Israel (Scott et al. 2021) suggest, there must have been a long tradition of date trade, which may also explain the date record from LBA Lachish.

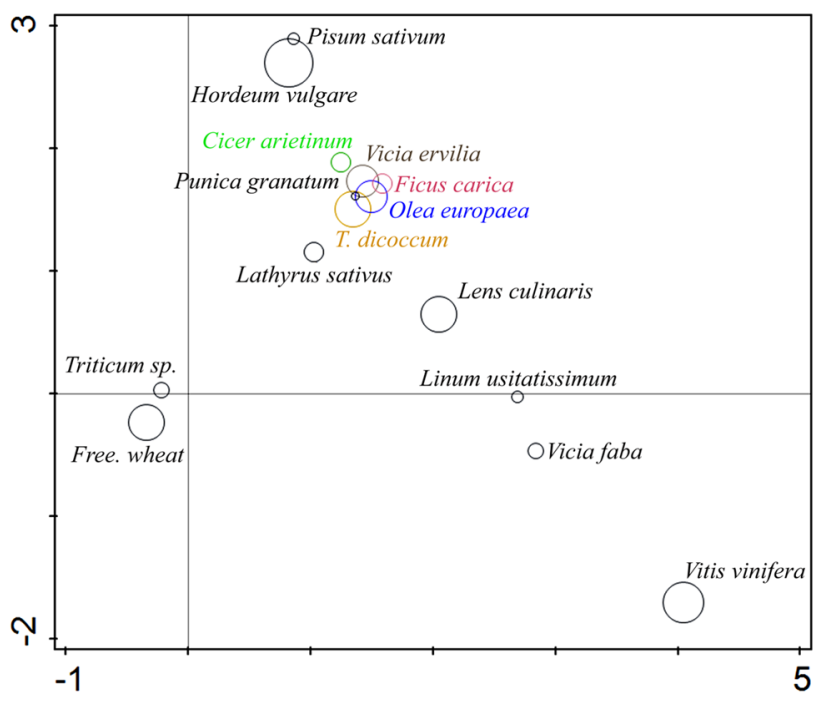

Fig. 9 Correspondence analysis biplot (following Fig. 8). Recurrence of crop taxa within the sites. FreeWheat free threshing wheat

The famous Lachish relief, carved by the Assyrians and depicting their siege and conquest of the city in $701 \mathrm{BCE}$, shows the most common fruits which are also represented in the archaeobotanical record, olive, fig and grape which represent the main fruits in the whole Mediterranean basin (Zohary et al. 2012).

Even though the relief was created in a period later than the contexts analyzed in this paper, it indicates that fruits were highly esteemed, and that fruit growing was well established in Lachish, since the Assyrians associated this with the identity of the city (ESM Fig. 2, Ussishkin 1982).

We found a large number of cultivated plants such as pomegranate from the LBA compared to the MBA and a drastic increase of cereals and fruit, in particular olive, grape and fig. These results match the pollen analyses which show a peak in the tree and shrub vegetation around the same period as the Egyptian texts which mention Lachish (Langgut et al. 2013). This is before the climatic drying at the end of LBA in the southern Levant, and also the increased importance of olive in the economy of Lachish that is possibly indicated by the appearance of new oil presses at various sites during this period (Onozuka 2012). Olive was one of the most important fruits of the eastern Mediterranean, since olive oil can be stored for long periods and, apart from daily diet, it was used for many other purposes (Zohary 1982). Thanks to their high tolerance to drought, olive trees are the optimal fruit crop for the Mediterranean ecosystem (Sofo et al. 2008).

Figs seeds represent $52 \%$ of the archaeobotanical assemblage in Lachish Area S, with more than $88 \%$ of them in the $\mathrm{S}-3$ samples. This seeming dominance of fig is biased by the fact that one fruit contains up to several hundred seeds. Figs 
played an important role in ancient diet and they could have been dried and stored for a long time, as with a Neolithic example from Gezer (Zohary 1982). Furthermore, they may represent animal feed as interpreted for EBA Tell Abu en-Ni 'aj where dung remains were found (Fall et al. 2015).

\section{Possible use of dung in Lachish?}

Dung has been identified from a number of sites in this area, although no dung remains have been found at Lachish up to now. It has been demonstrated that not all seed types survive animal digestion and would therefore be expected in dung (Miller and Smart 1984; Valamoti and Charles 2005). Apart from Tell Abu en-Ni 'aj, other sites in the southern Levant have yielded large amounts of Ficus carica and dung remains, such as MBA Tell el-Hayyat and Zahrat adh-Dhra (Fall et al. 2019) and IA Khirbat al-Mudayna al-Aliya (Farahani et al. 2016) (Fig. 1). However, each of these sites had a different setting, context and sources of fuel. Tell Abu en-Ni' ai and Tell el-Hayyat were two productive farming settlements, located in the northern Jordan valley. Here, the use of dung was identified from its remains, mostly material deriving from shrubs, fruit trees and riverside vegetation, mixed with charcoal. Khirbat al-Mudayna al-Aliya, located in west-central Jordan, depended strongly on dung, remains of which were found with small quantities of charcoal (Farahani et al. 2016). Zahrat adh-Dhra was an isolated farming settlement east of the Dead Sea, which relied more on desert trees than on dung for fuel. In the first three sites, the dung remains indicate that the livestock was feeding mainly on cereals and also grazing. At Khirbat al-Mudayna al-Aliya, the animals were probably kept inside the settlement, making the collection of dung easier. The botanical assemblage in Lachish is similar to these sites, even though it is hard to suggest that dung was used without a direct find. Once the results of the charcoal analysis are complete, it will be possible to understand more about the sources of fuel used at Lachish, considering the large quantity of charcoal and the differences in the results between areas $\mathrm{P}$ and $\mathrm{S}$.

Nonetheless, it is worth noting the presence of a tabun oven in Area S. As described by Dalman in his work Leben und Sitte in Palästina, on the customs and working traditions of the people living in the region during the first decades of the 20th century, dung cakes were still being used then to heat ovens for baking bread (Dalman 1935).

\section{Conclusions}

The results from Lachish confirm that the Shephelah area was good for the agriculture and subsistence of the communities that lived there. The high diversity, ubiquity and quantities of fruit remains in the archaeobotanical assemblage support the importance of fruit in the local diet. This is still true nowadays, since even though human activities have caused drastic changes to the landscape of the region throughout the centuries, there are still many vineyards spread across the fields below the tell.

The finding of a large number of fig seeds from Area S, combined with plant remains connected with animal feed, allow us to suggest the possible use of animal dung at the site. However, without actual evidence of dung, it is hard to determine whether the fig remains are related to fodder. However, remains of dung found at other sites in the southern Levant have yielded large numbers of fig seeds and a similar range of plant remains to the Lachish plant assemblage.

There is a significant change over time, since there are more cultivated plant taxa and an overall increase of remains in the LBA samples, compared to the ones from the MBA. The LBA remains from Area $S$ are much better preserved than from the MBA, even though the amounts of sediment collected for the two periods are rather similar. The two investigated areas differ completely in the preservation of their remains and probably also in their functions, considering their differing locations on the tell. It would be important for further analyses to expand the excavation and sampling of Area $\mathrm{S}$ to further understand the purpose of the monumental building and also of Area $P$ to shed more light on the function of the palace rooms.

Supplementary Information The online version contains supplementary material available at https://doi.org/10.1007/s00334-022-00873-2.

Acknowledgements This study is part of the SFB 1070 RessourcenKulturen A05 Teilprojekt (CRC Collaborative Research Center 1070 Resource Cultures A05 project) of the University of Tübingen. We would like to thank Jens Kamlah for his support, Christoph Forster for the data processing and design of the map and the area plans used in this paper and Shyama Vermeersch for proofreading our text. The Austrian excavations at Tel Lachish are directed by Felix Höflmayer and Katharina Streit on behalf of the Austrian Academy of Sciences and funded by the Austrian Research Fund START-grant "Tracing Transformations" (FWF Y-932 G25).

Funding Open Access funding enabled and organized by Projekt DEAL. The research conducted here was made possible by funding from the CRC 1070 ResourceCultures, project A05 at the University of Tübingen.

Data availability All data provided in the manuscript and supplementary material.

Code availability Not applicable.

\section{Declarations}

Conflict of interest The authors declare that they have no conflict of interest. 
Open Access This article is licensed under a Creative Commons Attribution 4.0 International License, which permits use, sharing, adaptation, distribution and reproduction in any medium or format, as long as you give appropriate credit to the original author(s) and the source, provide a link to the Creative Commons licence, and indicate if changes were made. The images or other third party material in this article are included in the article's Creative Commons licence, unless indicated otherwise in a credit line to the material. If material is not included in the article's Creative Commons licence and your intended use is not permitted by statutory regulation or exceeds the permitted use, you will need to obtain permission directly from the copyright holder. To view a copy of this licence, visit http://creativecommons.org/licenses/by/4.0/.

\section{References}

Aharoni Y (1975) Investigations at Lachish: The sanctuary and the residency (Lachish 5). Gateway Publishers, Tel Aviv

Bar-Matthews M, Ayalon A (2004) Speleothems as paleoclimate indicators, a case study from Soreq cave located in the eastern Mediterranean region, Israel. In: Battarbee RW, Gasse F, Stickley CE (eds) Past climate variability through Europe and Africa. Springer, Dordrecht, pp 363-391

Baas J (1980) Ein bedeutsamer botanischer Fund der Gattung Echium Linné aus Kamid el-Loz. In: Hachmann R (ed) Bericht über die Ergebnisse in Kamid el-Loz in den Jahren 1968 bis 1970. (Saarbrücker Beiträge zur Altertumskunde 22) Habelt, Bonn, pp 111-115

Behre K-E (1970) Kulturpflanzenreste aus Kamid el-Loz. In: Hachmann R (ed) Bericht über die Ergebnisseder Ausgrabungen in Kamid el-Loz (Libanon) in den Jahren 1966 und 1967. (Saarbrücker Beiträge zur Altertumskunde 4) Habelt, Bonn, pp 59-69

Bourke S, Sparks R, Schroder M (2006) Pella in the Middle Bronze Age. In: Fischer PM (ed) Thechronology of the Jordan Valley during the Middle and Late Bronze Ages: Pella, Tell Abu AL-Kharaz and Tell Deir 'Alla. Verlag der Österreichischen Akademie der Wissenschaften, Wien, pp 9-58

Bronk Ramsey C (2009) Bayesian analysis of radiocarbon dates. Radiocarbon 51:337-360

Carayon N, Morhange C, Marriner N (2011) Sidon's ancient harbour: natural characteristics and hazards. Archaeol Hist Lebanon 34(35):433-459

Dalman G (1935) Arbeit und Sitte in Palästina. Bertelsmann, Gütersloh. Digitized version 2013. http://nbnresolving.de/urn:nbn: de:bsz:21-opus-69119

Damick A (2019) The first identification of Phoenix dactylifera (date palm) from Early Bronze Age Lebanon. Veget Hist Archaeobot 28:583-589

Danin A, Fragman O (2016) Flora of Israel. https://flora.org.il/en/ plants/. Accessed 30 June 2021

De Moulins D (2015) Plant remains from middle bronze age to iron age: samples of the college site. Sidon Archaeol Hist Lebanon 42(43):32-54

Drori I, Horowitz A (1989) Tel Lachish: Environment and subsistence during the Middle Bronze, Late Bronze and Iron Ages. J Inst Archaeol Tel Aviv Univ 16:206-211

Epstein C (1963) A new appraisal of some lines from a long-known papyrus. J Egypt Archaeol 49:49-56

Fall PL, Falconer SE, Klinge J (2015) Bronze age fuel use and its implications for agrarian landscapes in the eastern Mediterranean. J Archeol Sci 4:182-191

Fall PL, Falconer SE, Porson S (2019) Archaeological inference of intermittent settlement and agriculture at Middle Bronze Age Zahrat adh-Dhra'1. Jordan. J Archeol Sci 26:101884

Farahani A, Porter BW, Huynh H, Routledge B (2016) Crop storage and animal husbandry at Early Iron Age Khirbat al-Mudayna
al-'Aliya (Jordan): A paleoethnobotnical approach. In: McGeough KM (ed) The archaeology of agro-pastoralist economies in Jordan. (Annual of the American Schools of Oriental Research 69) American Schools of Oriental Research, Boston, pp 27-89

Frumin SI, Melamed Y, Weiss E (2019) The wheat-people of Canaan. In: Maeir AM, Shai I, McKinny C (eds) The Late Bronze and Early Iron Ages of Southern Canaan. De Gruyter, Berlin/Boston, pp 19-36

Ganor S, Kreimerman I (2018) Tel Lakhish (Tel Lachish): preliminary report. Hadashot Arkheologiyot: (Excavations and Surveys in Israel 130) http://www.hadashot-esi.org.il/Report_Detail_ Eng.aspx ?id=25415

Garfinkel Y, Hasel MG, Klingbeil MG et al (2021) The Canaanite and Judean cities of Lachish, Israel: Preliminary Report of the Fourth Expedition, 2013-2017. Am J Archaeol 125:419-459

Golénischeff WS (1913) Les Papyrus Hiératiques Nos. 1115, 1116A et 1116B de l'Ermitage Impériale à St.- Pétersbourg. Manufacture des papiers de l'État, Saint Pétersbourg

Helbæk H (1958) Plant economy in ancient Lachish. In: Tufnell O (ed) Lachish (Tell ed-Duweir), vol 4: The Bronze Age. Oxford University Press, London, pp 309-317

Hepper FN (1992) Baker encyclopedia of bible plants: flowers and trees, fruits and vegetables, ecology. Three's Company, London

Jacomet S (2006) Identification of cereal remains from archaeological sites, 2nd edn. Basel University, Basel, IPAS

Jones G (1991) Numerical analysis in archaeobotany. In: van Zeist W, Wasylikowa K, Behre K-E (eds) Progress in Old World palaeoethnobotany. Balkema, Rotterdam, pp 63-80

Kagan EJ, Langgut D, Boaretto E, Neumann FH, Stein M (2015) Dead sea levels during the bronze and iron ages. Radiocarbon $57: 237-252$

Kislev ME, Mahler-Slasky Y (2009) Food remains. In: Gadot Y, Yadin E (eds) Aphek-Antipatris II: The remains in the Acropolis. Emery and Claire Yass Publications in Archaeology, Tel Aviv, pp 499-525

Kislev ME, Melamed Y, Langsam Y (2006) Plant Remains from Tel Batash. In. Panitz-Cohen N, Mazar A (eds) Timnah (Tel Batash) III: The Finds from the Second Millennium BCE. Qedem 45 Hebrew University of Jerusalem, Jerusalem, pp 295-310

Kislev ME, Simchoni O, Melamed Y, Maroz L (2009) Botanical remains: food and industrial crops. In: Panitz-Cohen N, Mazar A (eds) Excavation at Tell Beth-Shean 1989-1996, Vvl 3: The 13th-11th Century BCE strata in Areas N and S. Israel Exploration Society, Hebrew University, Jerusalem, pp 764-771

Langgut D, Finkelstein I, Litt T (2013) Climate and the Late Bronze Age collapse: new evidence from the southern Levant. J Inst Archaeol Tel Aviv 40:149-175

Langgut D, Finkelstein I, Litt T, Neumann FH, Stein M (2015) Vegetation and climate changes during the Bronze and Iron ages ( 3600-600 BCE) in the Southern Levant based on palynological records. Radiocarbon 57:217-235

Liphschitz N (2004) The archaeobotanical remains. In: Ussishkin D (ed) The renewed archaeological excavations at Lachish 19731994. Emery and Claire Yass Publications in Archaeology, Tel Aviv, pp 2230-2247

Ljubuncic P, Portnaya I, Cogan U, Azaizeh H, Bomzon A (2005) Antioxidant activity of Crataegus aronia aqueous extract used in traditional Arab medicine in Israel. J Ethnopharmacol 101:153-161

Mahler-Slasky Y, Kislev ME (2012) Preliminary archaeobo-tanical Research at Tell es-Safi/Gath - the 1997-2002 Seasons. In: Maeir AM (ed) Tell es-Safi/Gath I: The 1996-2005 Sea-sons, part 1: Text. (Ägypten und Altes Testament 69) Har-rassowitz, Wiesbaden, pp 579-587

Malleson C (2015) Archaeobotanical investigations at Tell El-Retaba. Egypt and the Levant 25:175-199 
Metzger MC (1984) Preliminary report of the first season of the Tell el-Hayyat Project. (Faunal and floral remains at Tell el-Hayyat. Preliminary results.). Bull Am Sch Orient Res 255:68-70

Migowski C, Stein M, Prasad S, Negendank JFW, Agnon A (2006) Holocene climate variability and cultural evolution in the Near East from the Dead Sea sedimentary record. Quat Res 66:421-431

Miller NF, Smart TL (1984) Intentional burning of dung as fuel: a mechanism for the incorporstion of charred seeds into the archaeological record. J Ethnobiol 4:15-28

Neef R, Cappers RTJ, Bekker RM (2012) Digital atlas of economic plants in archaeology. (Groningen Archaeological Studies 17) Barkhuis, Groningen

Nesbitt M (2009) Identification guide for Near Eastern grass seeds. Routledge, London

Nesbitt M, Samuel D (1996) From staple crop to extinction? The archaeology and history of hulled wheats. In: Paludosi S, Hammer K, Heller J (eds) Hulled wheats. Proceedings of the first International Workshop on Hulled Wheats, 21-22 July 1995, Castelvecchio Pascoli, Tuscany, Italy. (Promoting the conservation and use of underutilized and neglected crops 4) International Plant Genetic Resources Institute, Rome, pp 41-100

Olsvig-Whittaker L, Maeir AM, Weiss E, Frumin S, Ackermann O, Horwitz LK (2015) Ecology of the past - Late Bronze and Iron Age landscapes, people and climate change in Philistia (the southern Coastal Plain and Shephelah), Israel. J Mediterr Ecol 13:57-75

Onozuka T (2012) Keeping up with the demand for oil? Reconsidering the unique oil presses from Late Bronze Age IIB to Iron Age IIA in the southern Levant. Orient 47:67-90

Orendi A, Smejda L, Mckinny C, Cassuto D, Sharp C, Shai I (2018) The agricultural landscape of Tel Burna: Ecology and economy of a Bronze Age/Iron Age settlement in the southern Levant. J of Land Eco 10:165-188

Post GE (1980) Flora of Syria, Palestine and Sinai: From the Taurus to Ras Muhammad and from the Mediterranean Sea to the Syrian Desert. Periodical Experts Book Agency, Delhi

Rainey AF (2015) The El-Amarna correspondence: A new edition of the cuneiform letters from the site of El-Amarna based on collations of all extant tablets. (Handbook of Oriental Studies. Section 1, The Near and Middle East 110) Brill, Leiden

Ramsay J, Mueller N (2016) Telling seeds: archaeobotanical investigations at Tall al-'Umayri, Jordan. In: McGeough KM (ed) The archaeology of agro-pastoralist economies in Jordan. (The Annual of the American Schools of Oriental Research 69) American Schools of Oriental Research, Boston, pp 1-25

Reimer PJ, Austin WEN, Bard E et al (2020) The Intcal20 Northern Hemisphere radiocarbon age calibration curve (0-55 cal kBP). Radiocarbon 62:725-757

Rosen AM (1986) Environmental change and settlement at Tel Lachish, Israel. Bull Am Sch Orient Res 263:55-60

Rousou M, Parés A, Douché C, Ergun M, Tengberg M (2021) Identification of archaeobotanical Pistacia L. fruit remains: implications for our knowledge on past distribution and use in prehistoric Cyprus. Veget Hist Archaeobot 30:623-639. https://doi.org/10. 1007/s00334-020-00812-z

Schilman B, Ayalon A, Bar-Matthews M, Kagan EJ, Almogi Labin A (2002) Sea-land paleoclimate correlation in the Eastern Mediterranean region during the Late Holocene. Isr J of Earth Sci 51:181-190

Scott A, Power RC, Altmann-Wendling V et al (2021) Exotic foods reveal contact between South Asia and the Near East during the second millennium BCE. Proc Natl Acad Sci USA 118:e2014956117. https://doi.org/10.1073/pnas.2014956117

Simchoni O, Kislev ME, Melamed Y (2007) Botanica remains: BethShean as a trade center for crops in the Bronze Age, botanical and entomological evidence. In: Mazar A, Mullins RA (eds) Excavation at Tell Beth-Shean 1989-1996, vol 2. The Middle and Late
Bronze Age strata in area R. The Israel Exploration Society, Jerusalem, pp 702-715

Sofo A, Manfreda S, Fiorentino M, Dichio B, Xiloyannis C (2008) The olive tree: a paradigm for drought tolerance in Mediterranean climates. Hydrol Earth Syst Sci 12:293-301

Torczyner H, Harding GL, Lewis A, Starkey JL (1938) Lachish I (Tell ed Duweir): The Lachish letters. (The Wellcome-Marston archaeological research expedition to the Near East 1) Oxford University Press, London

Tufnell O (1953) Lachish III (Tell ed-Duweir): The Iron Age. (The Wellcome-Marston archaeological research expedition to the Near East 3) Oxford University Press, London

Tufnell O (1958) Lachish IV (Tell Ed Duweir): The Bronze Age. (The Wellcome-Marston archaeological research expedition to the Near East 4) Oxford University Press, London

Tufnell O, Inge CH, Harding GL (1940) Lachish II (Tell ed Duweir): The Fosse temple. (The Wellcome-Marston archaeological research expedition to the Near East 2) Oxford University Press, London

Ussishkin D (1982) The conquest of Lachish by Sennacherib. Tel Aviv University, Institute of Archaeology, Tel Aviv

Ussishkin D (2004) The renewed archaeological excavations at Lachish (1973-1944), vols 1-5. Emery and Clairs Yass Publications in Archaeology, Tel Aviv

Valamoti SM, Charles M (2005) Distinguishing food from fodder through the study of charred plant remains: an experimental approach to dung-derived chaff. Veget Hist Archaeobot 14:528-533

Van Zeist W, Heeres JAH (1973) Paleobotanical studies of Deir 'Alla, Jordan. Paléorient 1:21-37

Webster L (2020) Synchronising the chronologies of the Late Bronze Age southern Levant and Egypt: a radiocarbon dating perspective. Doctoral dissertation, University of Vienna and Macquarie University, Marquarie Park

Webster L, Streit K, Dee M, Hajdas I, Höflmayer F (2019a) New radiocarbon-based assessment supports the prominence of Tel Lachish during late Bronze age IB-IIA. Radiocarbon 61:1,711-1,727

Webster L, Streit K, Dee M, Hajdas I, Höflmayer F (2019b) Identifying the Lachish of papyrus Hermitage 1116A verso and the Amarna Letters: implications of new radiocarbon dating. J Anc Egypt Interconnect 21:88-99

Weissbein I, Garfinkel Y, Hasel MG, Klingbeil MG (2016) Goddesses from Canaanite Lachish Strata. Bull Ango-Israel Archaeol Soc $34: 41-55$

Wilcox G (1992) Preliminary report on plant remains from Pella. In: McNicoll AW, Edwards PC, Hanbury-Tenison J et al (eds) Pella in Jordan 2. The second interim report of the joint University of Sydney and the College of Wooster excavations at Pella, 1982-1985. Meditarch, Sidney, pp 253-256

Zaitschek DV (1961) Remains of cultivated plants from the caves of Nahal Mishmar: preliminary note. Isr Explor J 11:70-72

Zohary D, Spiegel-Roy P (1975) Beginnings of fruit growing in the old world. Science 187:319-327

Zohary M (1950) The segetal plant communities of Palestine. Vegetatio 2:387-411

Zohary M (1962) Plant life of Palestine. Ronald Press, New York, Israel and Jordan

Zohary M (1982) Plants of the Bible. Cambridge University Press, Cambridge

Zohary M, Hopf M, Weiss E (2012) Domestication of plants in the Old World: the origin and spread of domesticated plants in southwest Asia, Europe, and the Mediterranean Basin, 4th edn. Oxford University Press, Oxford

Publisher's Note Springer Nature remains neutral with regard to jurisdictional claims in published maps and institutional affiliations. 